\title{
An Interpolation Family in the Poetics
}

\author{
Michael M. Pozdnev
}

St. Petersburg State University,

7-9, Universitetskaya nab., St. Petersburg, 199034, Russian Federation; m.pozdnev@spbu.ru

For citation: Pozdnev M. M. An Interpolation Family in the Poetics. Philologia Classica 2020, 15 (2), 173-190. https://doi.org/10.21638/spbu20.2020.201

The ms. tradition of the Poetics is a mine, quite unexpectedly, when it comes to composition on literary matters: four independent witnesses - Parisinus 1741 (A), Riccardianus 46 (B), and mediaeval translations into Latin by William of Moerbecke and Arabic by Abü-Bishr Mattā made with the help of a Syriac interlinear (not to mention the recentiores which still could prove of some stemmatic value, as for instance Par. gr. 2038, Vat. gr. 1400, Berol. Philipp. and Mon. 493) - allow in most cases for a safe reconstruction of an archetype. Common errors suggest that this text differed from the autograph in some twenty passages, largely interpolations, ranging from a couple of words to a number of phrases. Several intrusions prove to be typologically close. All of them correct what was deemed to be inaccurate or loose argumentation by inserting syntactic complements or references adding cohesion. As a result, both the style and context go largely neglected. The first paragraphs of ch. 6, central to the Poetics, suffered most. This text also came down to us in a Syriac translation having a heavily glossed uncial ms. as its source. Insertions in ch. 6 cause 'harmonising' additions to the following text of the treatise. The 'family of interpolations' under discussion is tentatively attributed to a professor of Aristotelianism of late antiquity (the most suitable candidate seems to be Themistius): a school-room copy diffused by his pupils became the common ancestor of both the extant Greek mss. of the Poetics and the reconstructed Greek sources of the mediaeval translations. A fresh collation of the Syriac text together with the evidence of variae lectiones in the oldest independent Greek mss. offer a glimpse into the workings of his mind.

Keywords: Aristotle's Poetics, manuscript evidence, mediaeval translations, textual criticism.

* The work summarized in this paper is part of the project "Thesaurus criticus to Aristotle's Poetics" supported by the Russian Science Foundation (Project Nr. 18-18-0060). I am deeply indebted to Yury N. Arzhanov for all information concerning the Syriac translation, and to Michael N. Suvorov for his indispensable help in collating the Arabic one. I also want to thank Tatiana Kostyleva for valuable suggestions regarding both form and matter of what follows.

(C) St. Petersburg State University, 2020 
It is but common knowledge that the Aristotelian Poetics reached a wide intellectual public with the $16^{\text {th }}$ century translations and voluminous exegetic commentaries of which the outgoing Cinquecento already saw no less than six. ${ }^{1}$ Teachers of classics might know that this triumphal comeback had been prepared by the extensive scribal activity of late Byzantine and Italian copyists resulting in some 30 humanist mss. ${ }^{2}$ previous to the 1508 Aldine editio princeps. ${ }^{3}$ But probably only experts are aware of the fact that the Poetics was likewise popular with the mediaeval scribes and scholars, however peculiar its content may have appeared to their minds. The text is witnessed astonishingly well for a treatise on a matter in which the Middle Ages displayed little or no interest. ${ }^{4}$ Apart from some deeply contaminated recentiores that might still prove disputable as regards their provenance, ${ }^{5}$ the editors have at their disposal two Greek codices of equal stemmatic value, Parisinus gr. 1741 (A) and Riccardianus 46 (B), dating back to the $10^{\text {th }}$ and the $12^{\text {th }}$ centuries respectively, a Latin translation by William of Moerbecke made in 1278 from the ms. independent from either of these $(\Phi)^{6}$ and an Arabic translation by Abū-Bishr Mattā b. Yūnus created about the beginning of the $10^{\text {th }} \mathrm{c}$. (Ar) which, again, derives ultimately from a sovereign Greek source $(\Sigma) .^{7}$ To this comes a short fragment of the Syriac translation, cited by Jakob bar Shakko ( $† 1241)$ in his Book of the dialogues (Syr). The Syriac version is

${ }^{1}$ Listed by Schrier (1998, 21-30). The seventh could have been supplied by Gian Vincenzo Pinelli ( $\dagger$ 1601), but he did not manage to bring it to print. His ms., Ambrosianus 647 (P 204 sup.), consists of 51 fol. in Quadro covered with notes in Italian. Casual observation has revealed that Pinelli dealt rather with exegesis in general than with particular text issues. Of the "great commentaries" (cf. Weinberg 1953, 100) Vincenzo Maggi (1550) and especially Pietro Vettori (1560) are the most successful as concerns emendation.

2 A total of 39 late ms. dating from ca. mid $-15^{\text {th }}$ to the beginning of $19^{\text {th }} \mathrm{c}$. is now registered. 29 were collated by Lobel (1933); Harlfinger and Reitsch (1970, 37-42) added further two. All other collations including that made by Tarán for his and Gutas' 2012 "Editio maior" are selective. The collation of all known copies has been accomplished for Thesaurus criticus (see n. 1). The apographs prove to be of no little, should it only be heuristic, value, to say nothing of their importance for the reception studies, of which an instance is given in: Pozdnev 2019.

${ }^{3}$ Sicherl 1992, 113-116 supports Lobel 1933, 31-32 in assuming that its primary source has been Parisinus gr. 2038 corrected after Ambrosianus B 78 sup. However, in quite a few cases Ald. coincides with the corrections made in Berolinensis Phillippicus 1599 (196), but differs from the Ambrosianus.

${ }^{4}$ Strange as it might seem, no first-hand references to the Poetics by the Byzantine literates have so far been discovered. The thinkers of the Christian West ignored aesthetics. The Arabic poetics was too closely tailored to the local literary and linguistic context to be influenced by Aristotelian critical concepts. The only three original mediaeval philosophers, who make some use of them, largely misapprehending their actual meaning, are al-Fārābī, who was a student of Mattā in Bagdad, Avicenna and Averroes; their attitude is summarized in: Kemal 1991 and 2003 (here esp. 24-27).

5 This mostly refers to Parisinus gr. 2038 which has recently been discussed in: Taran 2016, in reply to Janko 2013. But Vaticanus gr. 1400, Berol. Philippicus and Monacensis 493, to cite just the most pertinent examples, also display peculiar readings and corrections probably inferred from an unknown apograph of A, or, less probably, $\Phi$, but not B which, contrary to Lobel $(1933,18 ; 30-31)$, was unknown to the humanist scribes. Corrections by the later hand could derive from the printed editions.

${ }^{6}$ Moerbecke's text (edited in 1953 by Minio-Paluello, Arist. Lat. vol. 33) is transmitted by two mss. (Toletanus Capit. 47.10, ca. 1280, and Etonensis 129, ca. 1300) which agree with each other in nearly all problematic cases.

7 The ms. is the celebrated Parisinus ar. 2346 (Ancien fonds Arabe 882 a) of the $11^{\text {th }}$ c., first published by Margoliouth (1887). On which see Gutas 1998, 147. The monumental posthumous edition by Tkatsch (Vol.I 1928, Vol.II 1932) is at some places supplemented and corrected by Gutas in his notes to the 'Editio maior'. 
supposed to have been the basis for the Arabic and thus the earliest surviving document of the tradition. ${ }^{8}$

The main branches of the paradosis are geographically and culturally dispersed so as to create an impression of far-reaching openness. There certainly existed an archetype $\left(\omega^{9}\right)$ other than in the hand of Aristotle himself or his writing attendants: a number of mistakes and omissions common to all mentioned witnesses are of a later origin; some of these we examine below in detail, and some are listed in the last footnote. But what could its nature possibly be? Was it a Late Ancient recension or a Byzantine school copy? Given the present state of knowledge, every date between ca. 80-60 BC (the famous Tyrannion's edition of Aristotle's and Theophrast's writings reported by Strabo $\left.{ }^{10}\right)$ and the mid- $9^{\text {th }} c$. $\mathrm{AD}$ (the latest possible date of the Greek ms. used by the Syriac translator ${ }^{11}$ ) can be considered. There remains uncertainty concerning the script of the hypothetic protograph. Was it in uncial letters or, perhaps, already in minuscule? Did it contain glosses or other comments in any form? To clarify all this is clearly a demanding task, as multiple transmission-indicative passages should be scrutinized. Yet there are some cases that seem to be especially instructive for elucidating the appearance of the common ancestor, while the data of textual criticism at our disposal are vast enough to promptly provide additional evidence. One such case is examined below. It is a series of analogous interpolations traceable in more than one passage of the Poetics, but mainly in the paragraphs following the definition of tragedy in chapter VI. This section is witnessed by all the aforementioned sources including the Syriac. It has been the object of most attention since the earliest stage of text reproduction: ${ }^{12}$ any scholar or copyist, ancient or mediaeval, could supply

8 As follows from the analysis by Gutas $(2012,108-109)$, partly confirmed by the collation carried out anew for Thesaurus criticus (see n. 1 above), the relationship between Ar. and Syr. is more complicated than usually assumed. That Abu-Bishr in some of his unfortunate renderings follows the Syriac source is fairly apparent. But it is likewise clear that other erroneous readings of Syr. are avoided in Ar.; for more details see below, n. 12, 15, 31 and 46.

${ }_{9} \Omega$ in Tarán's sigla, though the majuscule, perhaps, is more appropriate for the text written or dictated by Aristotle himself.

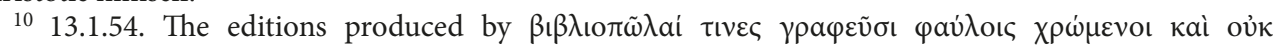

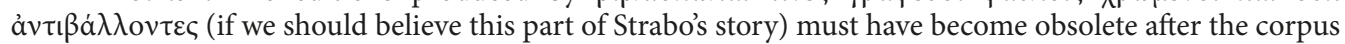
was edited anew by Andronicus who collated a lot of antigrapha and inscribed the rolls: Plut. Sulla 26; Porph. Vit. Plot. 24; for the discussion see Hatzimichali 2013, 15-23. That a copy of the Poetics in Andronican recension has survived to become an ancestor of $A, \Phi, B$ and $\Sigma$ is barely thinkable. But in any case, it might have been one of its descendants scattered in the ancient libraries, from which a number of mistakes and omissions (as in 1456a2-3 discussed below) were transmitted to the source of $\omega$.

${ }^{11}$ At present there is no certainty as to the terminus ante quem of Syr. and, respectively, of $\Sigma$. The only thing established so far is that, contrary to the earlier belief, the Syriac translation cannot be attributed to Ishaq b. Hunain, who flourished in the second half of the $9^{\text {th }} \mathrm{c}$. In a tentative 'scenario' Gutas considers the late $8^{\text {th }} \mathrm{c}$. as the approximate date of the Syriac translation. By that time the copies of Greek ms. containing the Poetics were kept in "the libraries of the Nestorian Christian monasteries in northern Iraq" (Gutas 2012, 108). Yury N. Arzhanov, who is about to give a new edition of fragmentum Syriacum, believes that by 780s the translation was already completed. The dating of Syr. largely relies on the interpretation of Patriarch Timothy's letters (Ibid. 80, test. 3-4) and cannot be discussed here at length. Anyway, there is all ground to conclude that the Eastern branch of transmission begins to ramify around 700, and thus the time span for an archetype in question should be narrowed to ca. $1^{\text {st }}-7^{\text {th }} \mathrm{c}$. which is an extended period indeed.

${ }_{12}$ The interest in enigmatic catharsis-formula is manifest already in neoplatonic scholarship (Iambl. Myst. 1, 11; Procl. In Plat. Rem publ. 1, 42, 10-16; Olymp. In Alcib. 54-55). It is then reflected in both Syriac and Arabic interpretative renderings of $1449 \mathrm{~b} 28-29$, but also e. g. in a gloss on $\dot{\varepsilon} \lambda \varepsilon \varepsilon 1 v \tilde{\omega} v$ (1452b32-

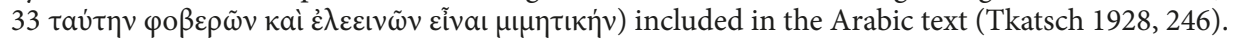


what he considered an improvement on the Aristotelian text and thought. In the following an attempt is made to detect traces of that work.

The first passage in need of revision is close to the beginning of the chapter. Having defined tragedy in a rather peculiar way, Aristotle then takes some care to clarify

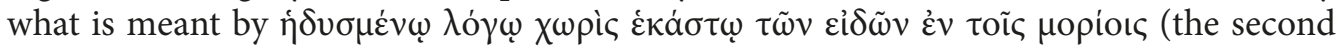
colon of the definition, $1449 \mathrm{~b} 25-26)$. This surely needs clarification, since $\dot{\eta} \delta v \sigma \mu \varepsilon \dot{v} v$ is metaphoric and the subordinate modifiers are arranged in an almost perplexing manner: it is quite clear, why both $\mathrm{A}$ and $\mathrm{B}$ read $\dot{\varepsilon} \alpha \dot{\sigma} \sigma \tau o v$, and the Eastern translations perceive $\chi \omega$ pi $\varsigma$ as a preposition, the implication being that $\Sigma$ could have had $\varepsilon \kappa a ́ \sigma \tau o v$ as well. The mistake ${ }^{13}$ caused by irregularity of expression is little informative for the filiation, especially as $\Phi$ seems to have escaped it: Moerbecke translates $\chi \omega$ pì by seorsum, not by sine. ${ }^{14}$ Equally confusing is the final syntagma. While $\mu$ ópıa (viz. $\tau \tilde{\eta} \varsigma \tau \rho \alpha \gamma \omega \delta i \alpha \varsigma)$ might be readily understood as 'smaller parts', or sections, of tragedy like prologue or stasimon, عi $\delta \eta$ is vague enough to encompass any meaning, either technical or not. Aristotle explains that 'sweetened' signifies metrical and musical forms of speech: $\lambda \dot{\varepsilon} \gamma \omega \delta \dot{\varepsilon} \eta \dot{\eta} \delta v \sigma \mu \dot{\varepsilon} v o v \mu \dot{\varepsilon} v$

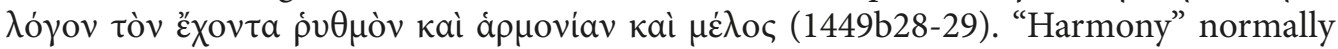
goes together with "rhythm" to signify two main musical means. Illustrative parallels in

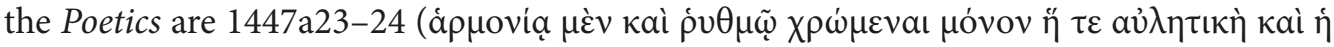
кıӨ

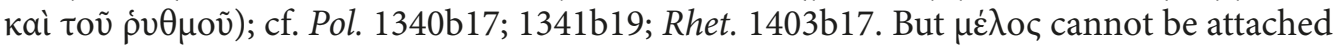

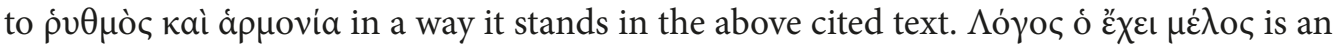
impossible expression. "Rhythm, harmony and song" looks absurd, because song virtually is speech embellished by rhythm and harmony. Kassel was right in following Tyrwhitt

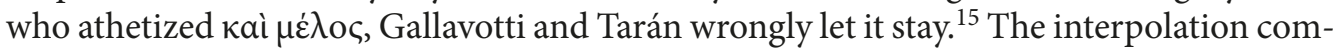
mon to all witnesses could not have been made independently by A, B, $\Phi$ and $\Sigma$. Supposedly, kaì $\mu \dot{\varepsilon} \lambda$ os goes back to the maker of $\omega$, whose reasons are shortly to be determined.

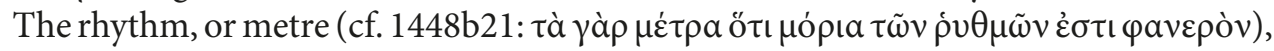

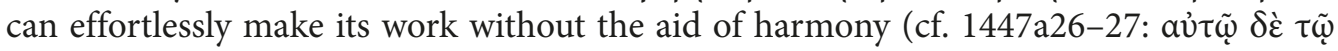

13 Emended by Reiz $(1786,12)$ and then by Tyrwhitt in the significant 1794 edition (pp. 137-138); the correct meaning is supposed already by Alessandro dei Pazzi's translation (a 1536 Aldine ed.) "separatim singulis generibus in partibus agentibus", though the parallel Greek text edited by his son Guillelmo reproduces the vulgate reading.

${ }^{14}$ Moerbecke's translation is very different from that of Mattā. The latter interprets almost every pattern he pretends to have understood, expands the original and glosses on it in trying to convey the meaning of things he had never heard of. What he creates is a chaotic combination of literalism and abstraction. In both he could have been misguided by the Syriac source (which he sometimes misreads). The Arabic of his translation is so bewilderingly confused that in many places the text is hardly readable at all. It must have been typical of all Mattäs translations (of which only the Poetics survives), and he was justly blamed for that by his contemporaries: Margoliouth 1905, 86. The text might have been an outline intended for those who were trained in Mattās school. On the contrary, Moerbecke is strict and cold. He uses no intermediaries and obviously does not need any. He strongly adheres to the style of mirror-translating, mastering it well enough to make an impression that he understands most of the patterns he writes about. In this he is greatly helped by the structure of Latin which is far closer to Greek than the Semitic languages. His wording is thoughtful but rather poorly chosen (cf. the indices in: Minio-Paluello 1953) and could serve the reconstruction of small words with far more certainty than that of Mattā.

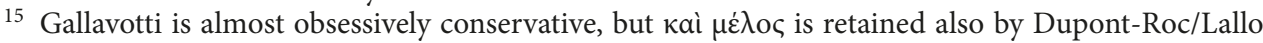
(1980) and Guastini (2010), to name the editors of the last decades. Vettori was the first to suspect $\mu \dot{\varepsilon} \lambda$ oc.

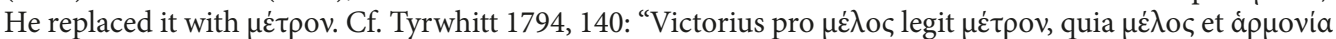

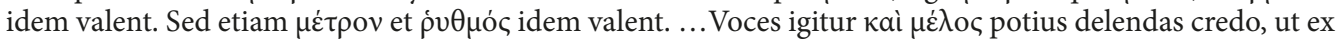
glossemate ortas." After Tyrwhitt the athetesis was argued for by Spengel 1841, 1263. 


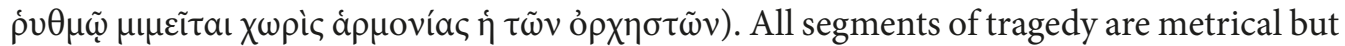
not all of them musical. This should help us to grasp the sense of a second Aristotelian

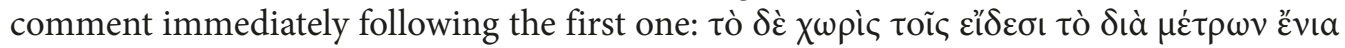

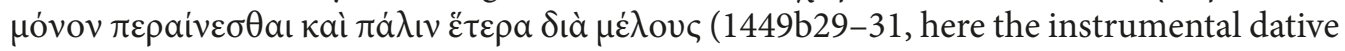
is reproduced by A, B and $\Phi$ thus justifying $\dot{\varepsilon} \kappa \alpha \dot{\sigma} \sigma \tau \omega$ in the preceding colon, whereas Syr.

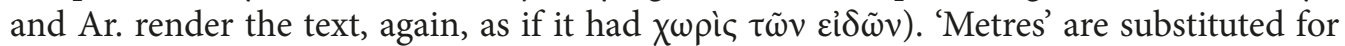
'rhythm', and thus one could infer (as Bywater actually did ${ }^{16}$ ) that 'song' is synonymous with 'harmony'. Yet, $\mu$ غ̇入 oc comprises both harmony and rhythm. Choral parts and monodies are, of course, metrical. Aware of this difference the interpolator pedantically added

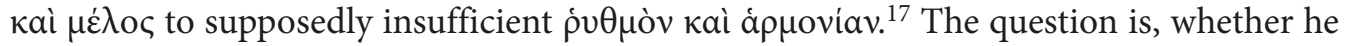
inferred the words himself or was it a transfer, more or less mechanical, from an annotated text, the motifs of an annotator being then purely didactic. The lengthier interpolations examined below might shed some light on this point.

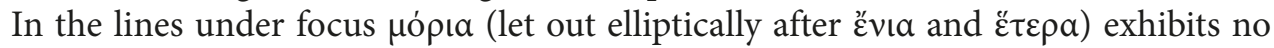
cladistic meaning, even less than in 1448b21, where it has the same etymological sense of a 'smaller part': metre is not a species, ${ }^{18}$ but one of the constituents, or properties, of rhythm (others being, for instance, tempo and intensity). Neither do $\varepsilon^{\prime} \delta \eta \eta$ bear any specific connotation. Aristotle avoids saying anything like "there are two kinds of speech embellishments"; he does not itemize $\varepsilon$ ह’ $\delta \eta \tau \tilde{\omega} v \eta \dot{\eta} \delta v \sigma \mu \alpha \dot{\tau} \tau \omega v$ in a way he enumerates and speci-

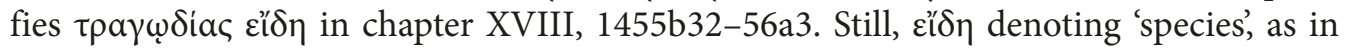
ch. XVIII, is so characteristic of his vocabulary that the word, especially accompanied by $\mu$ ópıa, is not so lightly passed by: it lingers in the reader's mind ready to be remembered on an appropriate occasion.

Next a reader is offered several appendices to the core definition. The description of the six 'parts', or 'elements', of tragedy is shaped in similar syntactic structures and remarkably

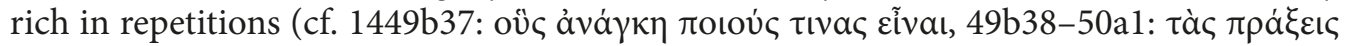

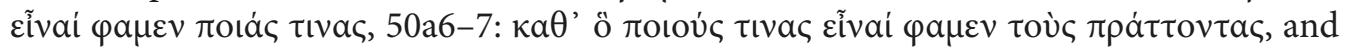

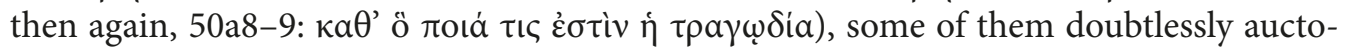
rial, others perhaps not. Initially, Aristotle employs the same term he has just used for the

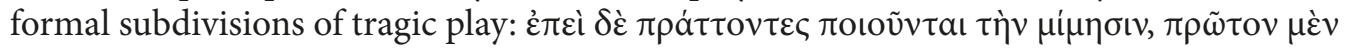

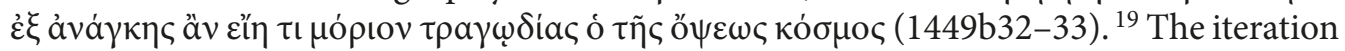

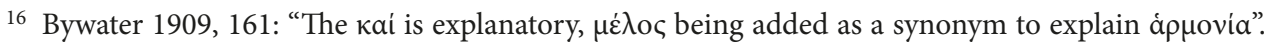

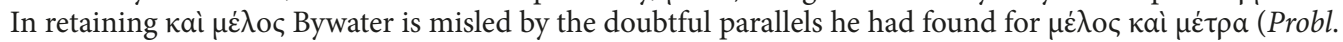

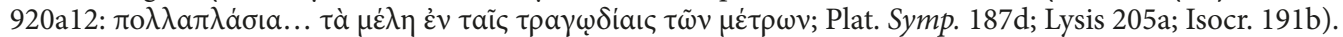
He seems to assume that Aristotle wanted to explain a more specific term with a common one. However, it is

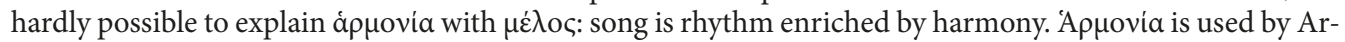
istotle in numerous difficult contexts without any explanation; á $\rho \mu o v i ́ a$ kai $\rho v \theta \mu o ́ \varsigma$ ("les élément mélodique et rythmique", as Dupont-Roc and Lallot elegantly put it) is utterly self-sufficient.

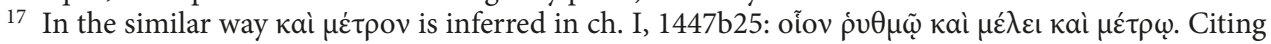

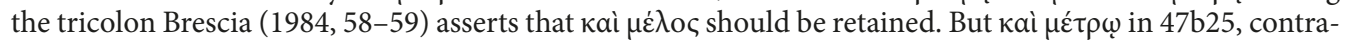

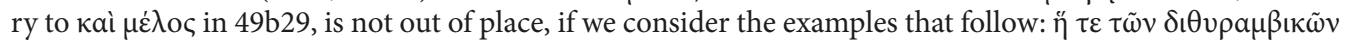

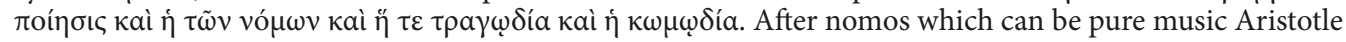
mentions the dramatic genres, and thus needs a specific element of rhythm appliable to them.

${ }^{18}$ Cf. Bywater 1909, 11: "Imitation, then, being natural to us - as also the sense of harmony and rhythm, the metres being obviously species of rhythms..." In contrast to other constituents of rhythm metres are 'fractional' ( $\tau \mu \eta \tau \dot{\alpha})$ and thus should not be used in oration (Rhet. 1408b29, Bywater's conjecture $\tau \mu \eta \dot{\mu} \mu \tau \alpha$ is misleading; cf. the commentary by Lucas 1972,74 ).

19 Aristotle makes little effort to fully elaborate his thought: the reader is left to conjecture, why the

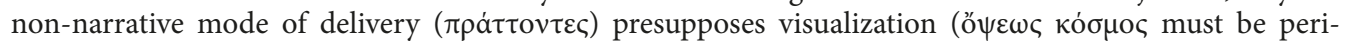


seems to be deliberate, albeit not intentional, as Aristotle adds $\tau \iota$, presumably to discern $\mu$ ópıov, here meaning 'constituent', from $\mu$ ópıa in the former paragraph. He then decides in favour of variety choosing $\mu \varepsilon \dot{\varepsilon} \eta$ to define basic components of the tragic genre. These he catalogues briefly, building on the classification of mimesis through media, modes and objects discussed in ch. I (1447a16-17).

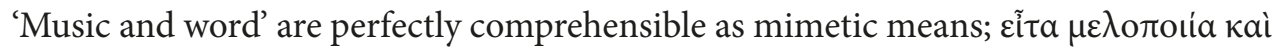

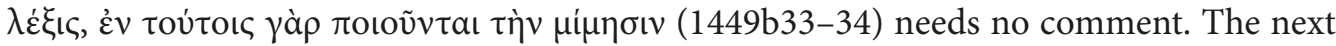
following explanation of $\lambda \dot{\varepsilon} \xi$ เ $\varsigma$ and $\mu \varepsilon \lambda$ o $\pi$ otia is not only superfluous, but bizarre in thought

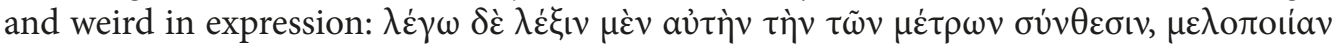

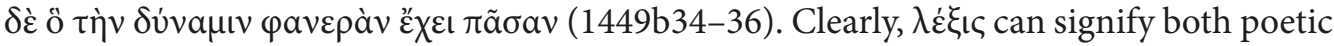
diction (as in 1449a23) and spoken dialect (1459a12, cf. Rhet. 1408b33). But, contrary to Bywater and others, it cannot possibly mean the "composition of verses", should it be used "in reference to the poet" ${ }^{20}$ or in any other reference. A few paragraphs later in the same chapter Aristotle gives an acute general definition of $\lambda \dot{\varepsilon} \xi$ Iৎ preceded by a back-reference:

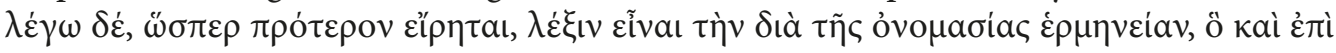

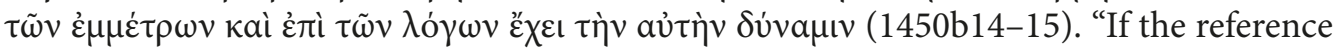
is to 6,1449b34", Bywater comments, "Aristotle must have forgotten [!] the exact terms of his previous formula." Still, to quote Bywater's next utterance, "the point is the same in both instances". ${ }^{21}$ This sounds even weirder than the above cited 'Aristotelian' passage. The "speech" that "interprets by giving names", and thus "has the same function in verse and prose" is evidently quite another thing than $\dot{\eta} \tau \tilde{\omega} \nu \mu \dot{\varepsilon} \tau \rho \omega \nu \sigma \dot{v} v \theta \varepsilon \sigma \iota \varsigma$, that is to say, the

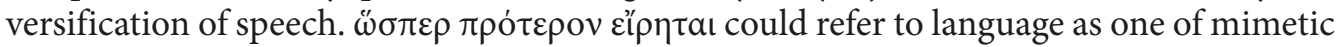
media. Much more credible, however, is that it is put forth by an interpolator with no other aim than to recall his own self-made definition.

The logic of $\lambda \dot{\varepsilon} \xi ı \varsigma$ defined as $\dot{\eta} \tau \tilde{\omega} \nu \mu \dot{\varepsilon} \tau \rho \omega \nu \sigma \dot{v} v \theta \varepsilon \sigma \iota \varsigma$ is easily discernible, indeed if we discredit its genuineness. Music encompasses rhythm, resp. metre. The reader easily infers it, because he was previously informed on what the speech embellishments are. But metre is formally absent, tragic play, we are told, has no media except $\mu \varepsilon \lambda$ o In an attempt to improve on this seeming shortage, the interpolator supplied a notion

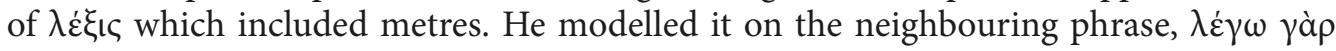

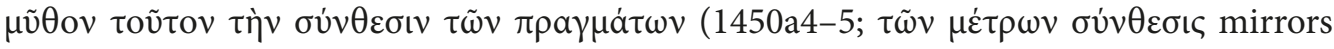

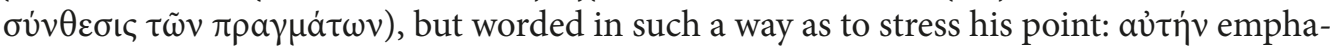

phrastic), especially as he knows that a tragedy goes perfectly well "without movement", its quality being

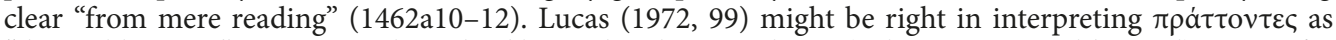
"the visible actors". A piece can be judged by reading but it is always (at least, to Aristotle's mind) written for staging. It is this uncertainty of expression that induces insertions.

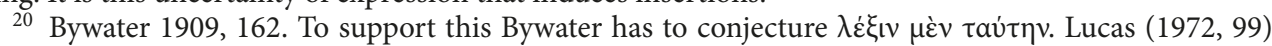

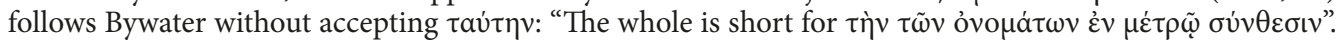
However, letting out the main term is a strange way to shorten, and the accent made on verse would, by all means, contradict the definition given in 1450b14-15. Gottfried Hermann boldly emends aủ

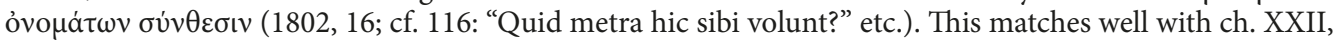

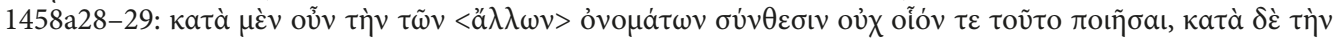

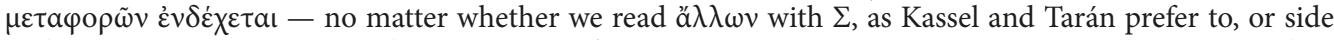

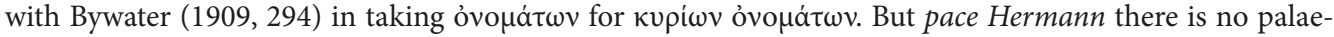
ographical support to his suggestion: even if contracted ỏvo $\mu \alpha \dot{\tau} \tau \omega \nu$ could not be taken for $\mu \dot{\varepsilon} \tau \rho \omega v$. Besides,

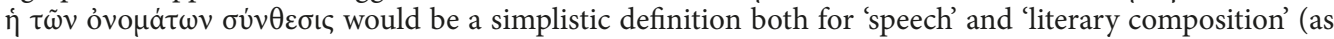
in Dionysius of Halicarnassus; the $\dot{\varepsilon} \rho \eta \eta v i$ a of Demetrius is evidently a more 'Aristotelian' term for that, cf. Poet. 1450 b14 cited above).

${ }^{21}$ Bywater 1909, 175. 


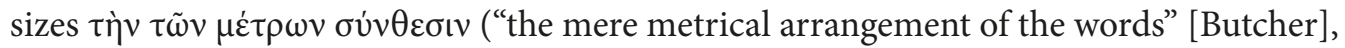
"l'agencement même des mètres" [Dupont-Roc/Lallot]). ${ }^{22}$ Having afterwards encountered the original definition he supplied the reminiscence cliché, perfectly careless about how to reconcile the two concepts. Moreover, he risked a further enhancement to the text he had before his eyes. In 1450b12-13, immediately before the back-reference, all ms. evidence

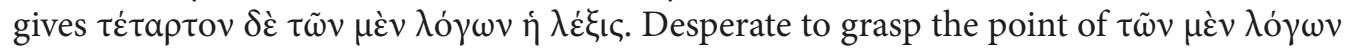
Kassel prints it sub cruce. The "speaking of words" is indeed pointless, but "speech as related to words", with defining genitive (as implied by $\mu \dot{\varepsilon}^{23}$ ), makes sense if opposed to the previously suggested idea of speech as dealing with metres. Tarán's decision to exclude it appears correct: the interpolator's obstinate endeavour to coordinate individual sections

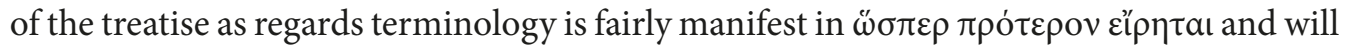
be observed again later.

The unassuming account of $\mu \varepsilon \lambda$ o $\pi$ olia as something "of which every function is manifest" is due to the same scholastic punctiliousness. With no new information provided

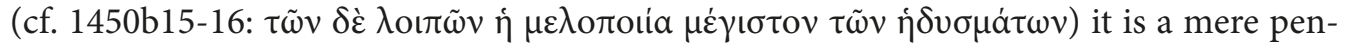
dant to the definition of $\lambda \dot{\varepsilon} \xi ı$. Besides, it is oddly formulated, $\pi \tilde{a} \sigma \alpha v$ being at times misread as $\pi \tilde{a} \sigma o v$ (and despondently replaced by it in the 1550 Maggi-Lombardi edition; cf. "a tutti può essere chiaro" [Guastini], "whose sense every one understands" [Butcher]) or

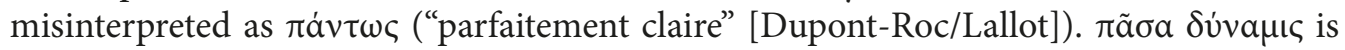

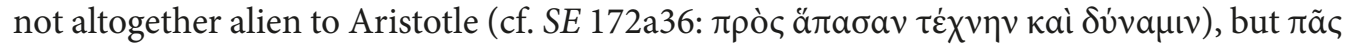
does not go well with $\delta \dot{v} v a \mu$, if the latter means 'function', or 'significance', as seems to be the case here. ${ }^{24}$ Yet, it becomes usable, if one perceives music as consisting of "rhythm, harmony and melos" and accordingly disintegrates its functions to evasively declare that none of these actually need explanation.

The syntax of the next lines (1449b36-1450a10, where the Syriac fragment ends), is confused to the point of incoherence; attempts to isolate interpolations have proved to be unsuccessful, though it is very unlikely that the text is authentic in every word. The paragraph starts with a protasis marker, but opinions widely differ as to where the protasis ends. Bywater punctuates the text as follows:

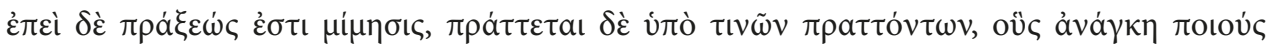

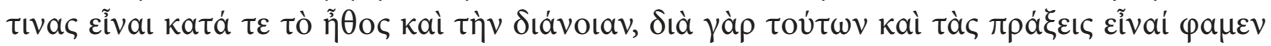

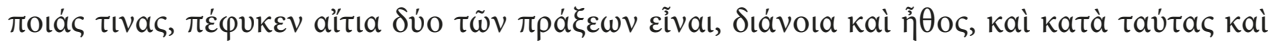

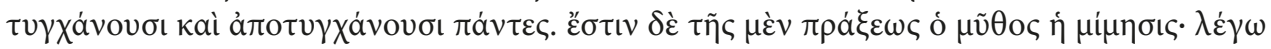

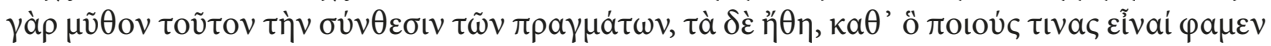

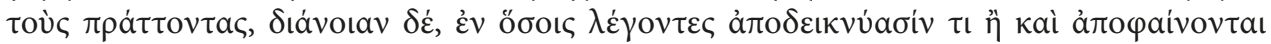

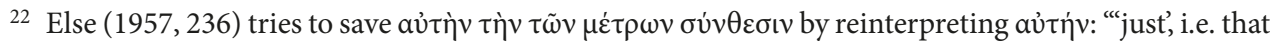

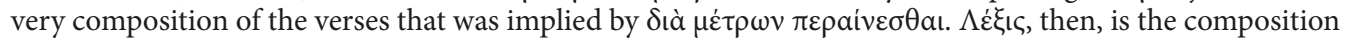
of the spoken verses, the dialogue." This was objected to by Verdenius $(1960,257)$ : “(1) 'just' is a very awkward way of referring to b30 and (2) it is very improbable that $\lambda \dot{\varepsilon} \xi ı$ c should be confined to the dialogue. The fact that in b30 $\mu$ óvov has been added to $\delta$ ià $\mu \dot{\varepsilon} \tau \rho \omega v$ shows that $\mu \dot{\varepsilon} \tau \rho o v$ in itself does not denote a dialogue."

${ }^{23}$ In a late humanist Cod. Ferrarensis Cl. II. $348 \mu \dot{\varepsilon} v$ is left out: its maker must have been embarrassed by the emphasis laid on $\tau \tilde{\omega} v \lambda \hat{o} \gamma \omega v$. Normally, the learned copyist follows Vettori, but in this case he took the decision upon himself.

${ }^{24}$ Cf. Dupont-Roc/Lallot 1980, 53. Schmitt $(2008,9)$ fancifully translates: "dessen wirkende Kraft ganz im Äußeren präsent ist", but this is too complicated for a clarification, the pregnant meaning of pavepáv requiring a further comment. 


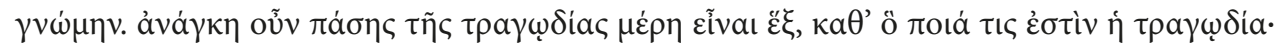

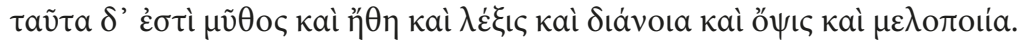

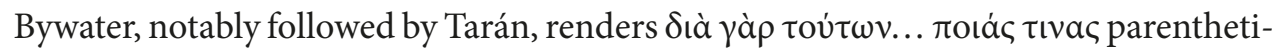

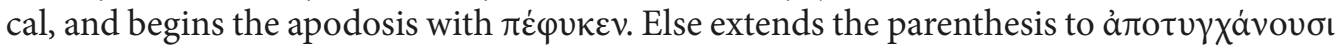
$\pi \dot{\alpha} v \tau \varepsilon \varsigma$, athetizes $\pi \dot{\varepsilon} \varphi v \kappa \varepsilon v . . . \tilde{\eta} \theta$ oৎ (1450a1-2), ${ }^{25}$ and stretches the $\dot{\varepsilon} \pi \varepsilon \dot{l}$ clause out up to

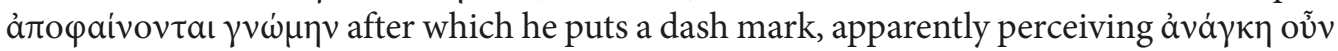
$\kappa \tau \lambda$. as the main clause. In fact, those are the only two options we have. ${ }^{26}$ But neither is eligible. As to the suggestion of Else accepted by Kassel, it is hardly feasible that from the speculations on characters and plot of tragedy there should follow that their constituents are six in number. ává $\gamma \kappa \eta$ oũv announces a new thought sequence which briefly summarizes the whole section on $\mu \varepsilon \dot{p} \eta$ : the number of 'parts' is given and then expanded in a list (put in brackets by Else but, inconsequently enough, not by Kassel). Bywater's solution seems more attractive, as it shortens the protasis and avoids elimination. Yet the reasons Aristotle gives for introducing $\delta ı \alpha$ voı $\alpha$ and $\tilde{\eta} \theta$ oc into his analysis of tragedy, namely that the acting persons will necessarily exhibit certain moral qualities and make certain judgements, would provide no premise for asserting that there happen to be just two causes of action, and that it is by their actions that everyone's successes and failures are conditioned.

Accordingly, we have either to consider the text incurably corrupt, or to venture an emendation. Aristotle's primary concern is to introduce two new evaluation criteria.

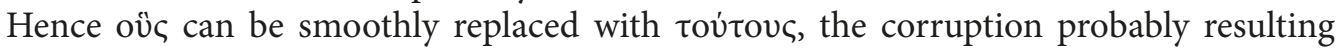

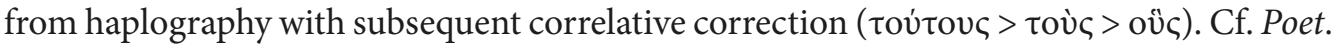

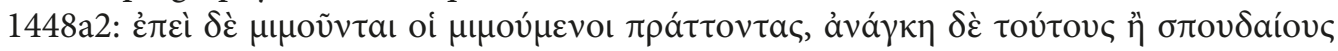

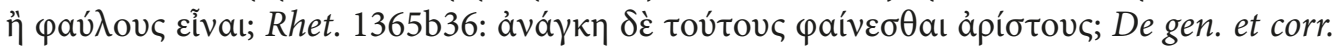

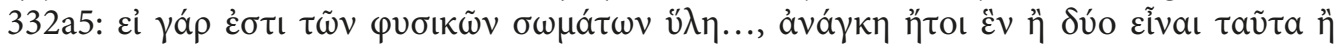

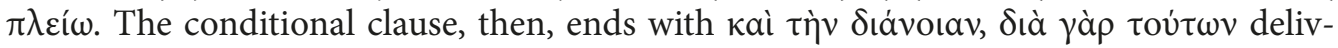
ering an additional argument, quite naturally, in a separate colon. The next segment is meant to be parenthetical, since the connective particle is lacking. $\pi \dot{\varepsilon} \varphi v \kappa \varepsilon v$ eqs. cannot be straightforwardly athetized, least of all because it "was intended as a paraphrase of $\delta$ ı̀̀ $\gamma$ à $\rho$

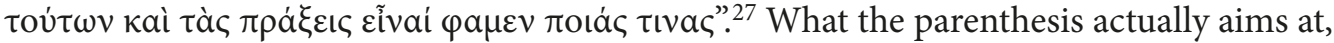
is to supply a passing comment on why actions are commonly qualified by characters and thoughts of the agents. ${ }^{28}$ Its first section points out at the causes of actions (the accent lies on $\tau \tilde{\omega} \nu \pi \rho \dot{\alpha} \xi \varepsilon \omega \nu$ ), while the second (with slightly adversative kai) deals with their results.

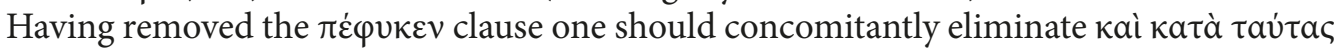

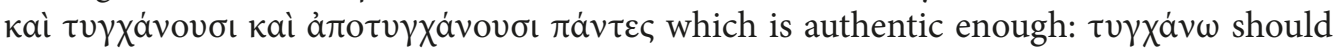
be considered synonymous with $\dot{\varepsilon} \pi \imath v \gamma \chi \chi \alpha{ }^{\prime} \nu \omega$ which in the Aristotelian corpus is used elsewhere in the same combination (EE 1247a36). The text seems not sound, but its content is adequate, the reason for bracketing it away being merely formal.

The main obstacle to rendering the afore-cited section coherent (provided we read

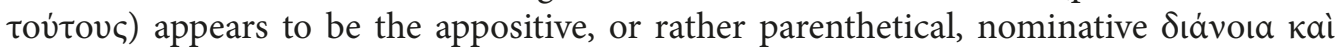

25 See Else 1957, 240, with n. 68. Else gives a sound criticism of the attempts of Vahlen and Gomperz to transpose the segment.

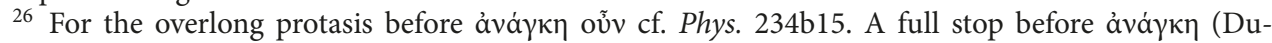

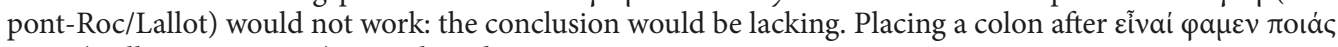
tıvac (Gallavotti 1974, 20) is an absurdity.

27 Else 1957, 240.

28 The detailed analysis is given in Schmitt 2008, 354-357. 


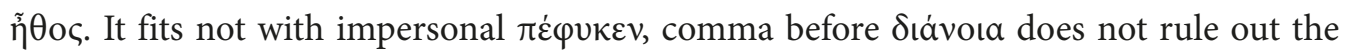

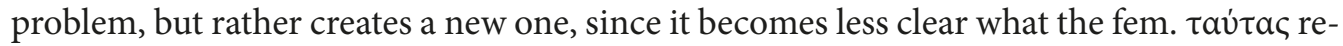

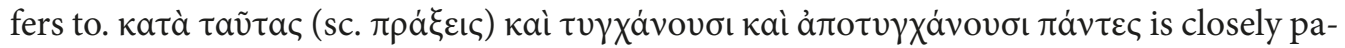

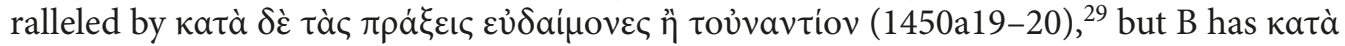
$\tau \alpha \tilde{v} \tau \alpha$ and the Syrian translates likewise ${ }^{30}$ possibly following the mistake of his source. We should therefore accept $\delta$ iávorav which is the reading of A. However, it is an easier reading and looks very much like a copyist's correction. Suppose Aristotle has omitted the

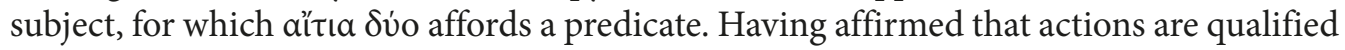
by character and thought, he goes on to say that these are by their nature the two causes of action. The interpolation technique, into which some insight has been gained above, consists in filling up the seeming gaps with gloss-like additions. Thus, an interpolator would

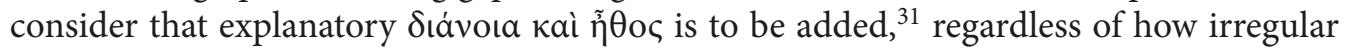
such a parenthesis might be. This neglect of syntactic framework will be illustrated below by further examples.

The insertions identified so far are, of course, purely conjectural. If the uncorrupted text was previous to the archetype in question, it can hardly be witnessed anywhere except a secondary source. Yet we are almost completely ignorant about the number of intermediaries between Aristotle and $\omega^{32}$ or between the latter and our earliest mss. Some interpolations might have been originally added over the line to be inserted in the main text

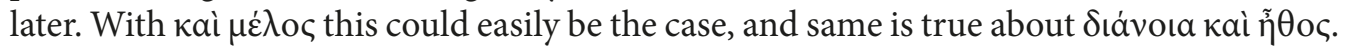
Hope remains, therefore, to detach supplements that left traces in the ms. tradition, all the more so because the tradition is, as seen above, remarkably ramified.

The Aristotelian account of "the parts of tragedy" closes with the enumeration linked

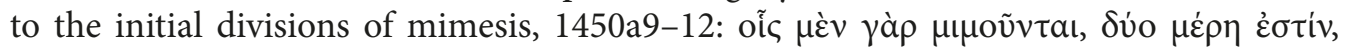

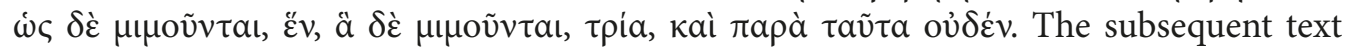
(1450a12-15) in Kassel's edition resembles a graveyard:

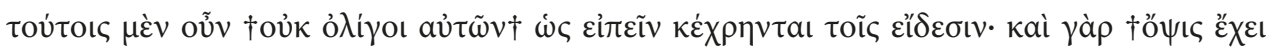

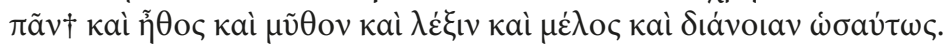

29 Cf. Valgimigli $1937,7$.

30 The same is to be found in Mattäs version, while Moerbecke translates secundum has. In fact, it is just one of many cases where $\Sigma$ displays common mistakes with B against $A, \Phi(\Pi)$. The following sampling from cap. I-XII illustrates that the current consensus which makes all extant Greek mss. descendants of a common ancestor (Tarán's $\Xi$ ) independent of $\Sigma$ must not necessarily be followed: 1448b26: tà

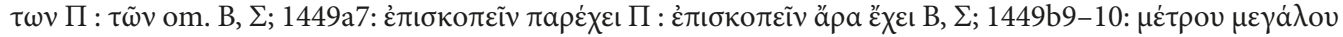

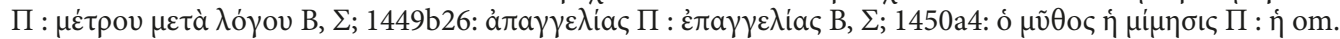

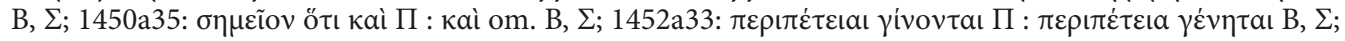

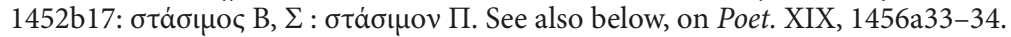

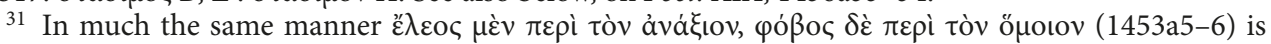

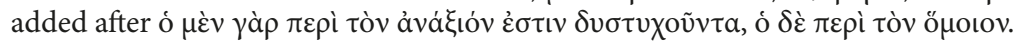

32 For the pre-Andronican (Apellicon's?) editions see Hatzimichali 2013. To what extent the non-Aristotelian material was incorporated in the Andronicus edition, is not our task to discuss. F. Grayeff (1956) assumes that the text of the Poetics then published was to a great extent a mixture of Aristotle's thought and

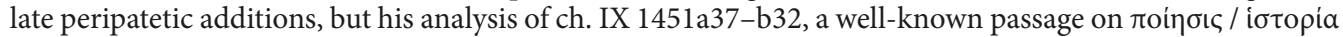
and on 'giving names', condemned as incongruous and thus partly an interpolation, is not very convincing:

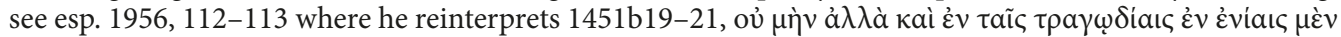

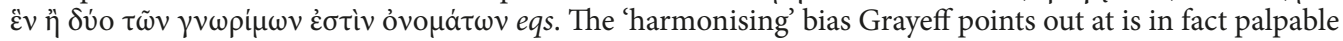
throughout the treatise. But to discern the genuine links resulting from the author's wish to string together parts of a larger whole from what is "incongruous and merely "harmonized"' one should base on the actual incongruities in the transmitted text and not on the faulty notions he pretends to read into it. 
There is enough reason to side with Kassel in considering the passage largely inexplicable, even if the segments he obelizes might actually be explained away or emended

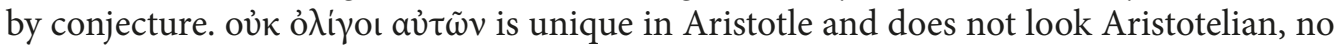
more than the nonchalant omission of the substantive ( $\delta \rho \alpha \mu \alpha \dot{\tau} \omega \nu$ rather than $\pi$ oin $\left.\tilde{\omega} \tilde{\omega} \nu^{33}\right)$

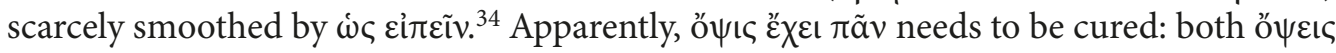
and ö $\psi \iota v$ can be found already in the late mss., and the editions differ respectively. Yet the problem recognized by Kassel lies not here, but in $\pi \tilde{\alpha} v$, evidently meaning $\pi \tilde{\alpha} \nu \delta \rho \tilde{a} \mu \alpha$. Even if Aristotle would think of $\delta \rho \tilde{a} \mu \alpha$ as a plain synonym for tragedy in this context, he would hardly have omitted it. Apart from being useless for the analysis, the whole phrase is painfully trivial and consists mostly of repetition. Together with stylistic discrepancies this more than suffices to consider it an insertion, though question remains as to its purpose, since it does not at all look like a gloss nor, at least prima facie, like a correction of an alleged incongruity.

To answer this, we have to take a closer look at $\varepsilon^{\prime \prime} \delta \varepsilon \sigma \iota v$. The use of $\varepsilon^{\prime \prime} \delta \eta$ in lieu of $\mu \varepsilon \dot{\rho} \eta$ is evidently a mistake. That these are not interchangeable follows from ch. XXVI 1462b16-

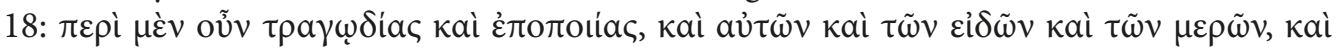

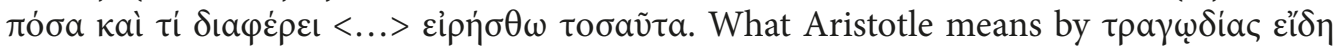
is lucidly defined in ch. XVIII, 1455b32-1456a3, the section being crucial for the understanding of how $\omega$ could have been created. In Tarán's edition the text runs as follows:

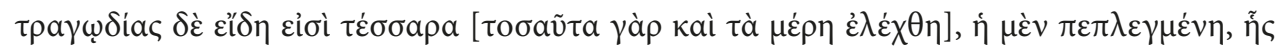

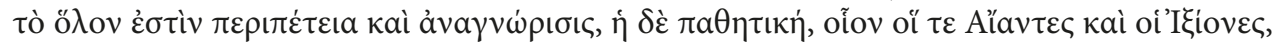

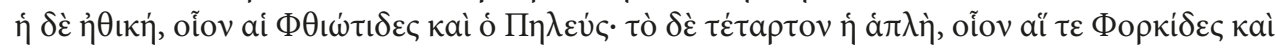

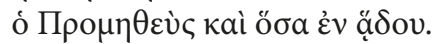

At first, a note is required about $\dot{\eta} \dot{\alpha} \pi \lambda \dot{\eta}$ which is not a manuscript reading but an emendation by Conrad Bursian. ${ }^{35}$ Actually, the idea is some three centuries older: $\dot{\alpha} \pi \lambda \grave{\eta}$

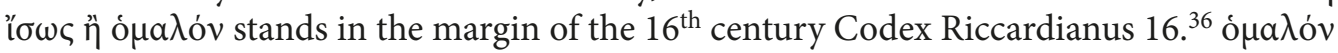

33 This is presupposed by the following $\pi \tilde{a} v$. According to Else $(1957,249)$, "the rationale of the passage

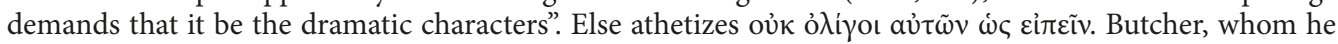

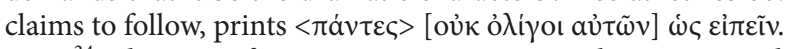

34 Placing it after $\pi \tilde{\alpha} v$, as Bywater tentatively suggests in the apparatus, would deprive it of its justifying

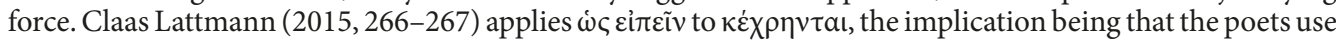
the elements of tragedy insufficiently: "Sie ,nutzen' sie nur, insofern sie sich ausschließlich der ö $\psi$ ıৎ widmen, die ja qua Modus der Tragödie alles beinhaltet; eine intendierte und zielgerichtete Nutzung im eigentlichen

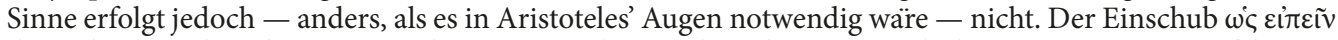
dient damit mehr oder weniger als Ironiesignal - und spielt zum Zweck des argumentativen Effekts am Beginn des neuen Unterabschnitts zugleich mit der inhaltlichen Paradoxie, die die Aussage im Kontext impliziert und die für die bisherige Forschung eben der Stein des Anstoßes war: Nicht wenige ,nutzen' alle

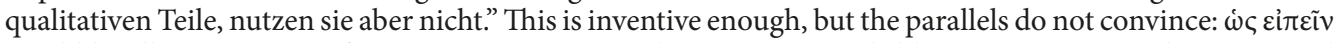

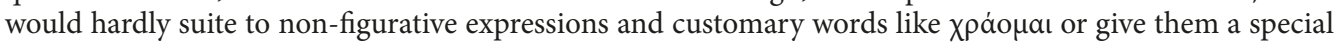

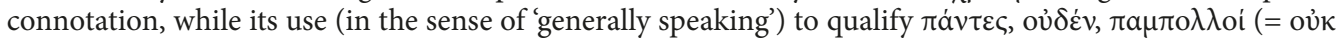
ó $\lambda(\gamma o \iota)$ and the like generalizing quantitative words is supported by dozens of passages. Hence Bursian

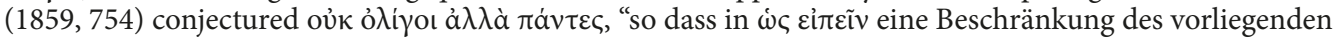

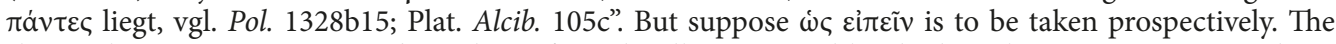
skeptical overtone in Lattmann's reading of it is hardly supported by the harmless enumeration, with no discernible stress on ö $\psi \iota \varsigma$, presented in the next phrase.

35 Bursian 1859, 757; Tarán $(2012,280)$ wrongly ascribes it to Susemihl. Schrader suggested $\tau \varepsilon \rho \alpha \tau \tilde{\omega}-$ $\delta \varepsilon \varsigma$, which has gained much approval among the late 19th c. editors: Bywater 1909, 250.

${ }^{36}$ Morel - if the notes to the 1555 Paris edition printed by him were by his hand - proposed to read $\dot{\alpha} \pi \lambda$ oṽv (not $\dot{\alpha} \pi \lambda \tilde{\eta}$, as in the reference by Pia Pattoni 2012, 159, n. 5), see [Anonymus] 1555, 83. 


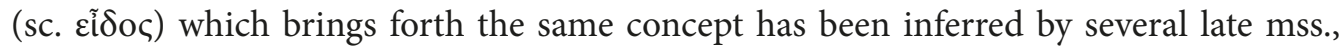
and accepted in the once famous edition of Charles Batteux. ${ }^{37}$ Originally it was meant as a correction of the inexplicable form on previously named $\pi \varepsilon \pi \lambda \varepsilon \gamma \mu \varepsilon \dot{\varepsilon} \eta \eta$ and participates among the 'species' of epics enumerated

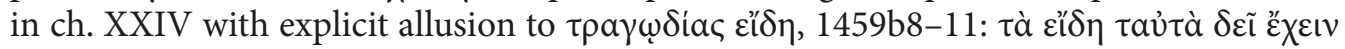

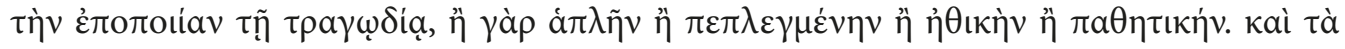

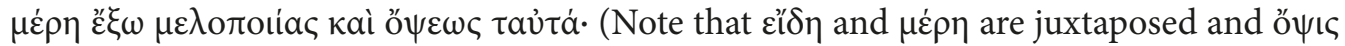
listed among the latter.) Unmistakably, the fourth 'kind' of tragedy is meant to be $\dot{\alpha} \pi \lambda \dot{\eta}$. And yet, it turns to be out of place in view of the examples that follow. One might try to argue that Prometheus Bound (if this Aeschylean tragedy is meant) and the Satyr play The Daughters of Phorcys by the same author (F 261-262 Radt) lack peripety and recognition

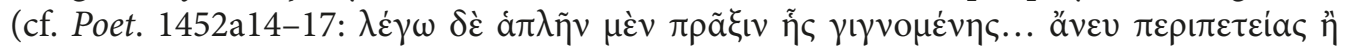

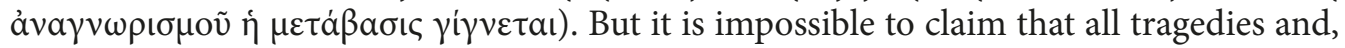
by implication, all Satyr plays the action of which takes place in the underworld are of the similar 'plain' composition. ${ }^{38}$

Intriguingly enough, $\mathrm{B}$ coincides with $\mathrm{A}$ in presenting the unmeaning on $\varsigma$ written in a very peculiar, unmatched, manner - $\mathrm{OHC}-$ as if the scribe suddenly decided to use

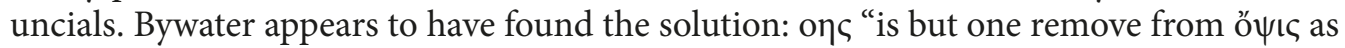
it might be written in an uncial ms. $(\mathrm{OHC}=\mathrm{O}+\mathrm{IC})$ ". ${ }^{39}$ Kassel disbelieves this printing on under crosses in his usual agnostic manner. Tarán's treatment of the text is, on the contrary, quite heavy-handed. on cannot be straightforwardly replaced with á $\pi \lambda \dot{\eta}$, because there is one more passage in the Poetics where both A (blindly followed by a number of de-

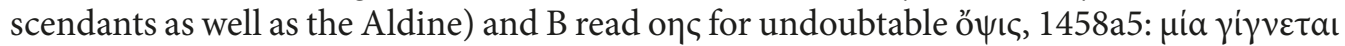
ả $\mu \varphi$ ot $\rho^{\rho} \omega v$ oै $\psi$ (Empedocl. B 88 DK); Aristotle had in mind the contracted form (cf. a4-5:

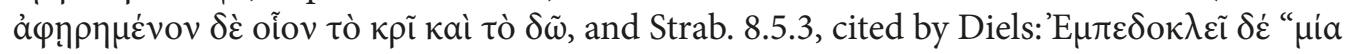

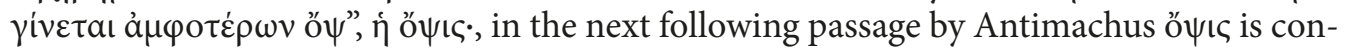
tracted in the same way), but a copyist unthinkingly inscribed a commonly known word. The parallel, also noted by Bywater, speaks strongly in favour of his conjecture: $\omega$ most

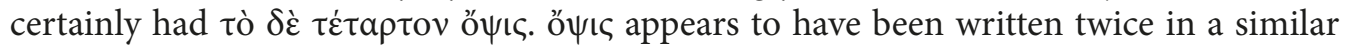
confusing manner - a trait of personal ductus. Coincidentally, tò $\delta \dot{\varepsilon} \tau \dot{\varepsilon} \tau a \rho \tau o v ~ O H C$ was carefully transcribed to finally survive in B. And certainly, Prometheus, Phorcides and "all those that take place in the underworld" should more suitably be called impressive in spectacle than simple in composition. ${ }^{40}$

37 See Batteux 1771, 150, with n. 3. He refers to the same reading in Cod. Par. gr. 2117. Cf. c. XV,

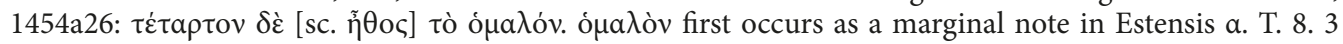
(= Puntoni 100), where it might have been inserted by Giorgio Valla who owed the codex (Lobel 1933, 3). In his 1498 Latin translation Valla renders the locus quarta porro aequabilis. John Rhosus who wrote Laurentianus plut. 31. 14. conjectured oikẽov, and the same reading intruded into Par. Coislinanus 324 which also has ó $\mu \alpha \lambda$ òv in the margin. Among numerous emendations listed by Pia Pattoni $(159$, n. 12; 184-185)

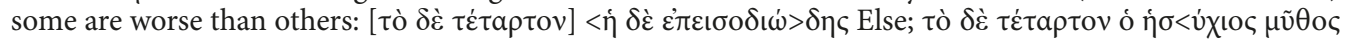

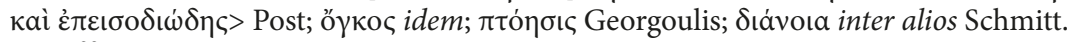

38 Cf. Pia Pattoni 2012, 160: "non risulta del tutto perspicuo perché i drammi ambientati nell’Ade (ö $\sigma \alpha$

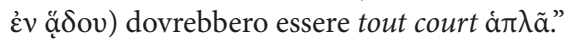

39 Bywater 1909, 250.

40 Cf. Pia Pattoni 2012, 161-162. Like many before her (Rostagni, Valgimigli, Janko, Dupont-Roc/ Lallot et al.), Pia Pattoni stands for the authenticity of ö $\psi \iota \varsigma$. But note that ö $\psi \iota \varsigma$ and $\dot{\alpha} \pi \lambda \dot{n}$ cannot replace each other: the Iliad which is plain in action is less spectacular than the Odyssey which is complex. 


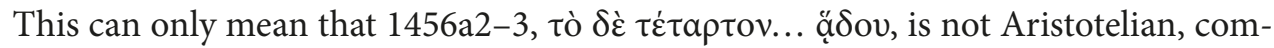
posed most likely to fill in a break in the given text. The majuscule insertion should be dated at the latest to ca. mid- $8^{\text {th }}$ century, ${ }^{41}$ but it could have been of much earlier origin, since the author has no difficulty in telling which ancient plays are eye-catching enough

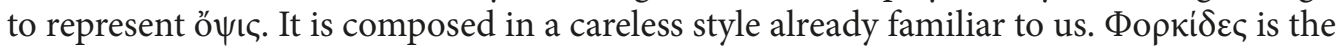
only Satyr play mentioned in the extant text of the Poetics, ${ }^{42}$ and it is recalled to exemplify the species of tragedy. ö $\psi ı$ ı markedly differs from the other three 'kinds', not least because of its syntactical inconsistency, so we ought to ask how the interpolator came to the idea to supply it. The answer is partly provided by another striking insertion of the same origin.

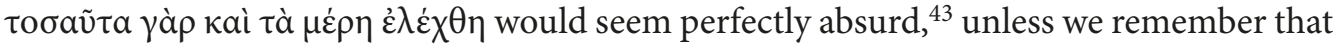
with all his negligence as to the appropriateness of the utterances, intended to be explanatory, the interpolator is painstakingly scrupulous about the terminological coherence. He does not bother himself with the actual number of $\mu \dot{\varepsilon} \rho \eta$, but considers it important to remind that the newly introduced concept of 'kinds' strictly corresponds to the preceding notion of 'parts'. His point, clearly indicated by $\gamma \alpha \dot{\alpha} \rho$, is to link $\varepsilon ı \delta \eta \eta$ and $\mu \dot{\varepsilon} \rho \eta$ together into a kind of terminological unity. This allows him to further add one of the 'parts', to the insufficient list of the 'kinds'. So, he simply transfers ö $\psi$ is from the catalogue in ch. VI without even trying to better adjust it to the new setting.

The interpolation method we attempt to observe can be called retrospective: insertions never build on what follows which suggests that they were made in the very process

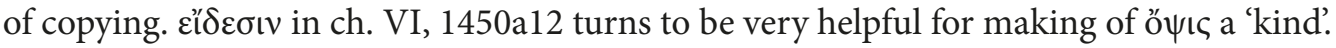
But it could not have appeared in ch. VI in support of what is asserted in ch. XVIII. Like all other additions, it should have been founded on what precedes. That would cause us to

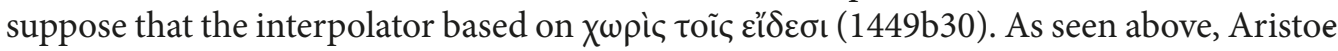
tle describes verse and music as 'kinds', or means, of speech embellishment. Using eí $\delta \eta$ to recapitulate the constitutive elements of tragedy would imply a shift of meaning. The effort it would require is quite needless in view of the possibility to employ the obviously

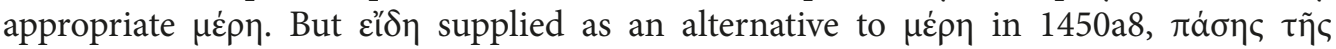

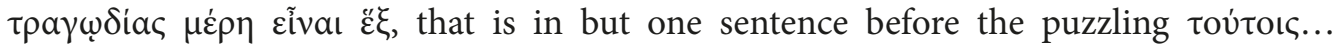

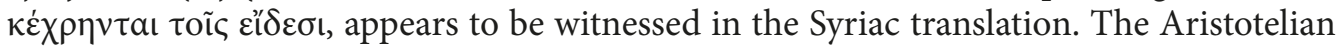
text is incorporated by Bar Shakko in a leapfrog manner: he starts with the definition of

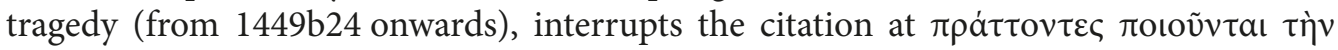

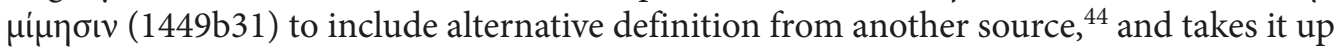
again at $\pi \dot{\alpha} \sigma \eta \varsigma \tau \tilde{\eta} \varsigma \tau \rho \alpha \gamma \omega \delta$ íac. What he quotes here is literally to be rendered as follows: "so, the kinds, that is the parts, of tragedy are six in number". 'Kinds' and 'parts' are linked together by the exegetic particle usually introducing a gloss-like explanation (dra). Let-

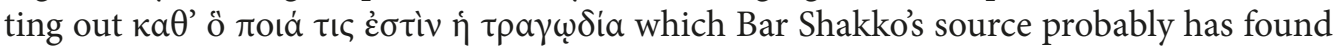

${ }^{41}$ See $n$. 54 below.

${ }^{42}$ It remained unnoticed by Schoder 1969, 75; hence, perhaps, the common opinion according to which the Satyrs are lacking in the Poetics.

${ }^{43}$ Allen $(1972,81-82)$ proposes to refer it to another work, or "supplementary material", but such a 'blank' reference would be unparalleled; one should at least expect something like $\dot{\varepsilon} v$ úto Allan is right, why what was four in the scholarly remarks turned to be six in the treatise we read. Are we left to conjecture about the 'parts' that were at first considered irrelevant?

44 "Some claim that tragedy means something mournful <..." There follows a quote from the Psalms (6:7) in Peshitta version. On the sources of Bar Shakko Arzhanov will have plenty to say in the forthcoming edition of Syr. 
unessential the citation proceeds then up to $\mu \varepsilon \lambda$ otolia (1450a10) and is again interrupted by summarizing remark: "these are the six kinds of tragedy that we find according to Aristotle's view". After that the compiler jumps back to the section corresponding to $\dot{\varepsilon} \xi$

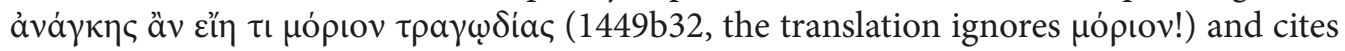

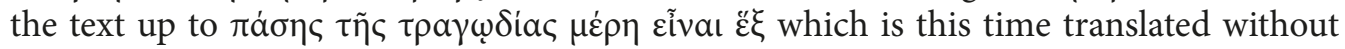
interpretative additions but with an allusion on what precedes: "Therefore it is necessary that every tragedy should have six parts - those which we have mentioned above". Since the 'kinds' are 'mentioned above' twice in the same context, it can be claimed that $\varepsilon^{\prime} \delta \eta$, if

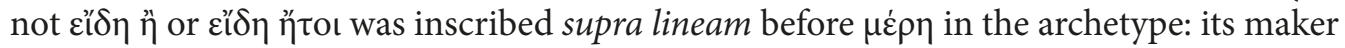
might have recalled the word from previous paragraphs and jumped to the occasion to employ the 'Aristotelian' term. Most copyists ignored his note, not least because of its inappropriateness, but it intruded in the text on which the Syriac translation was based. ${ }^{45}$

We cannot be sure, of course, that 'kinds' is not an invention of an intermediary Syriac source. But even if it was never present in any Greek ms., its reflections in Bar Shakko's

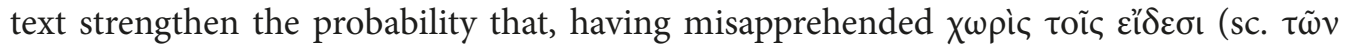
$\grave{\eta} \delta v \sigma \mu \alpha \dot{\tau} \tau \nu$ ), the interpolator regarded $\varepsilon^{\prime} \delta \eta$ as a near synonym of $\mu \dot{\varepsilon} \rho \eta$. He might even have thought it a better suited term, and, with typical pedantry, considered it important to supply a side remark in which it would replace $\mu \varepsilon \dot{\rho} \eta$ to denote the constituents of tragedy.

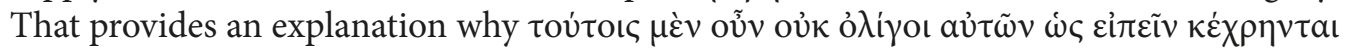

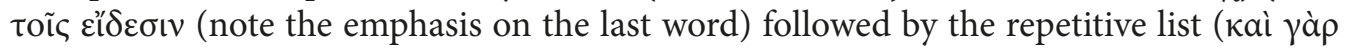
ö $\psi$ is eqs.) came into being. What remains of chapter VI is a prolonged argument in favour of the priority of $\mu \tilde{v} \theta \circ \varsigma$ (1450a15-b4), the hierarchy of remaining components appended. Hence, for an insertion aimed at stressing $\varepsilon^{\prime} \delta \eta \eta$ no better place could have been found.

Curiously enough, the extant witnesses allow to reconstruct the same interlinear

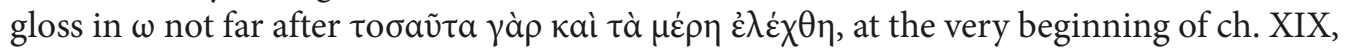

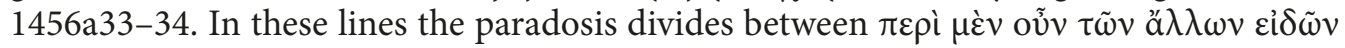

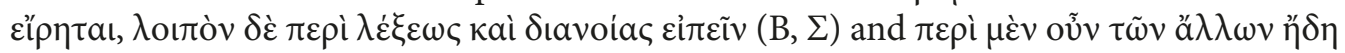

45 In reflecting the Greek Syr. displays gaps and errors where Ar. appears faultless. The new collation of Syr. carried out by Arzhanov for Thesaurus criticus (see n. 1) has revealed that in reflecting the Greek Ar. and Syr. have common mistakes to which, however, only Syr. adds its own. These are: 1449b29: है $\chi 0 v \tau \alpha$

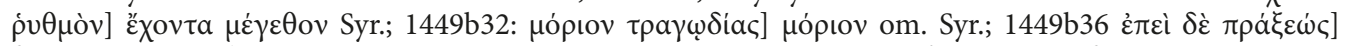

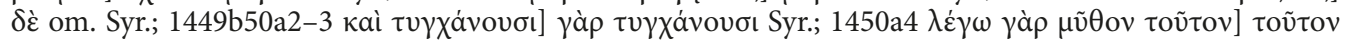

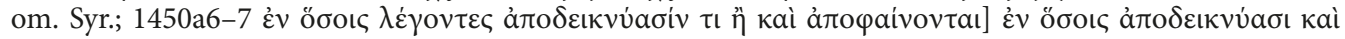

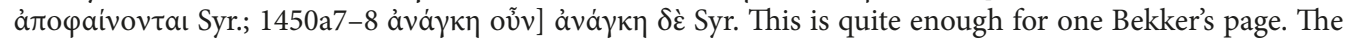
divergences are small, but distinct. Gutas (2012, 101-102) claims that Ar. stems from the revised version of Syr. But it remains obscure who would carry out such a revision (it could hardly have been Ishāq b. Hunayn), and why would he do that kind of editorial work instead of simply translating the text anew. In trying to frame this into his revision scenario Gutas (109) is forced to admit the existence of Greek ms. other than $\Sigma$ : "Syriac translation itself was revised... on the basis of other, unknown, material, which conceivably could have included another Greek ms. $(\Psi)$ ". The latter probably "belonged to the apographs of the hyparchetype manuscript of the Syro-Arabic tradition" (103). Our conclusion would be that the Greek ms. used for the Syriac translation was copied from the ms. used for the Arabic one. Abu-Bishr had the Syriac text before his eyes. That is confirmed, apart from the common interpretations, by Ibn al Nadīm's statement in Kitäb al Fihrist. In stating that Mattā was translating from the Syriac Nadīm uses the word tafsìr (lit. 'interpretation'): this can be a synonym to naql ('translation'), but also could mean specifically interpretative translation. Mattā is explicitly called 'Greek' (which can, of course, mean 'Christian') and could hardly have escaped knowing some Greek, living and teaching in a Syriac monastery (Deir Qunna). We cannot be sure that all his Arabic translations listed in Fihrist were from Syriac only: these works are not attested. But his manner of translating allows to suggest that he was compiling from the Greek and the Syriac. He consulted the latter source for interpretations, probably because it was glossed. 


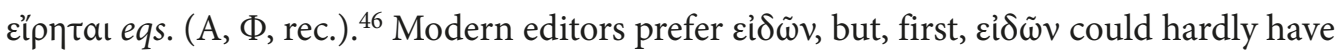
turned into $\eta \delta \eta$ : the words are not similar either by appearance or by spelling (even considering the itacism; besides, the Byzantine scribes were trained to be very sensitive about accents). Secondly, only some few lines above the term was given quite another meaning. However, $\eta \delta \eta$ appears too sophisticated for a scribe's conjecture, and if we admit that a

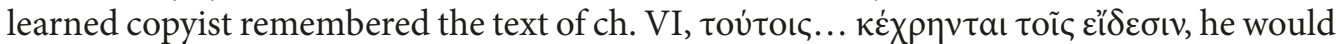
have considered $\varepsilon i \delta \tilde{\omega} v$ acceptable like the current scholarship do. ${ }^{47}$ Still, to decide for $\eta \hat{} \delta \eta$

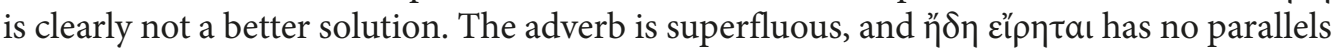

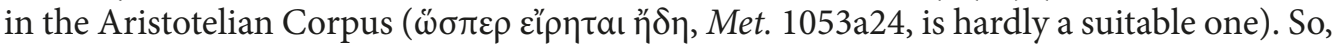
we are left to suggest that $\varepsilon \dot{i} \delta \tilde{\omega} v$ and $\eta \eta \delta \eta$ originate from a common source that allowed both readings. This must have been $\varepsilon^{\prime \prime} \delta \eta$ originally inscribed over the text between $\tau \tilde{\omega} v$

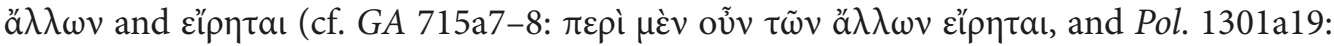

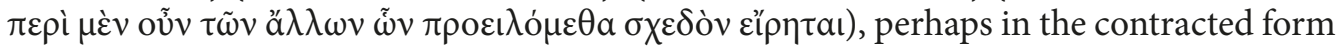
EI $\Delta$ - since A actually has $\eta \delta^{\prime}$. The ancestors of B and $\Sigma$ interpreted that as a genitive, whereas those of $\mathrm{A}$ and $\Phi$ decided for an adverb in a mistaken itacistic spelling. It is also thinkable that the maker of $\omega$ implanted $\varepsilon^{\prime \prime} \delta(\eta)$ into the text before $\varepsilon^{\prime \prime} \rho \eta \tau a l$ (cf. the un-

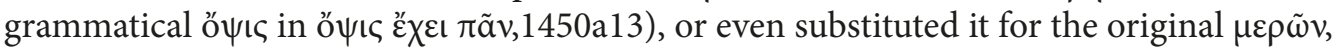

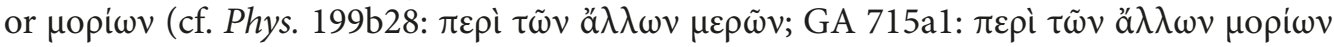

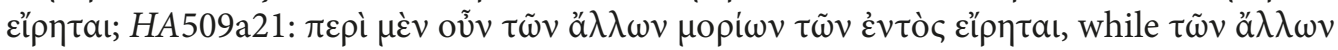
$\varepsilon i \delta \tilde{\omega} v$ occurs nowhere else in the Corpus).

The above-described treatment of the source text is surely very frivolous, and even

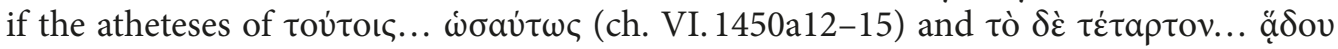
(ch. XVIII.1456a2-3) would prove irrefutable, strong doubt persists that the insertions were meant as embellishments of a text to be widely read. The last related passage we are going to examine might bring more clarity to this issue. The following phrase marks the beginning of what in most editions is printed as ch. XII of the Poetics, 1452b14-16:

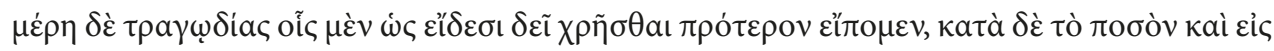

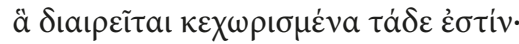

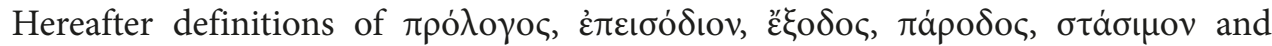
$\kappa о \mu \mu$ ó are given, and the chapter is concluded by almost verbatim repetition of the passage (1452b25-27) in which, however, $\omega \varsigma \varepsilon \varepsilon \delta \varepsilon \sigma \sigma$ is skipped. It is absent in all extant branches of transmission and thus was most probably omitted in $\omega$, though without it $\delta \varepsilon \tilde{\imath}$ turns to be pointless: it is fairly absurd to require from tragedy the use of its constitutive elements such as plot or characters. To be sure, $\dot{\omega} \varsigma \varepsilon^{\prime} \delta \varepsilon \sigma \mathrm{l}$ is essential: it is this syntagma that renders the phrase comprehensible - if, of course, we read it as interpolation effected by the same person whose techniques we have surveyed above. Provided our assumptions are true, his intention here is the same that he demonstrates later, in ch. XVIII: "parts that are to be used as (= identical with) kinds" is another clumsy attempt to reconcile the authentic $\mu \varepsilon \dot{\varepsilon} \eta$ with the interpolated $\varepsilon \varepsilon^{\prime} \delta \eta$ which to his mind was a more appropriate term to convey abstract meaning. Thus, $\dot{\omega} \varsigma \varepsilon^{\prime} \delta \varepsilon \sigma \mathrm{l}$ is indispensable in the first transition clause. But are we to follow those who restore it in the second, as Kassel and Tarán actually do?

46 Cf. above, n. 31.

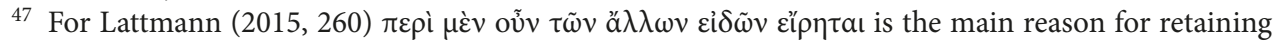
$\varepsilon \varepsilon^{\prime} \delta \varepsilon \sigma \iota v$ in $1450 \mathrm{a} 13$. He does not discuss the alternative reading. 
This is a more complex question than it might seem. The suspicion that the segment containing definitions of the structural components of tragedy is out of place in the Aristotelian Poetics is as old as the post-humanist age: Heinsius tried to relocate ch. XII, ${ }^{48}$ it was proscribed by several $19^{\text {th }}$ century scholars ${ }^{49}$ and then by Else, who retains only the

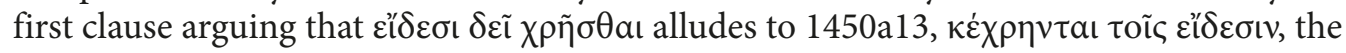
words he deems authentic. ${ }^{50}$ In supposing this he fails to recognise the difference between $\mu \dot{\varepsilon} \rho \eta$ and $\varepsilon^{\prime} \delta \eta$, and makes no effort to explain the point of $\dot{\omega} \varsigma \varepsilon^{\prime \prime} \delta \varepsilon \sigma$. He believes that $\mu \dot{\varepsilon} \rho \eta$

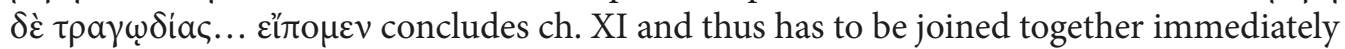
with the beginning of ch. XIII. That makes his arguments for athetesis insufficient. The

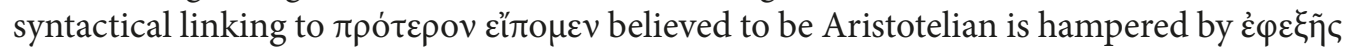

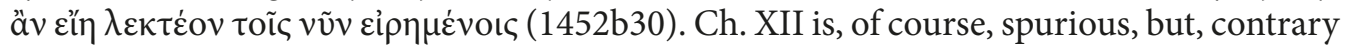
to Else, not on the grounds that it breaks the connection between chapters XI and XIII.

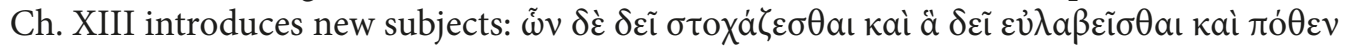

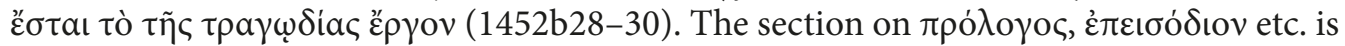
incorporated right at the watershed where the descriptive part of the Poetics ends and the prescriptive begins. This is just the proper place to include a few paragraphs on a special topic. Consequently, the dismissal of ch. XII should comprise its first colon not excluding

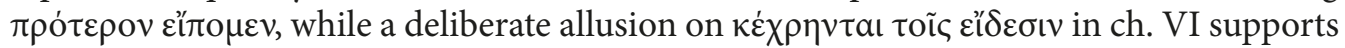
its athetesis.

What is offered in ch. XII is indeed a "purely mechanical division based on no principle and carried out in a crudest possible manner". ${ }^{51}$ But it is not primarily because of this that the section should be excised. More important is the fact that whatever the target audience of the Poetics might have been, it is for his contemporaries that Aristotle was writing. It would be ridiculous to explain them that a prologue is "that part of tragedy which precedes the entrance of the chorus", or that stasimon is a choral song "without anapests and trochees". On the contrary, a late ancient or early mediaeval professor would certainly try to explain it to his students. A modern lecturer on ancient tragedy would likewise think that without defining its formal divisions his lectures would be incomplete.

Now, the author of ch. XII writes in the first person pointing at the authorship of

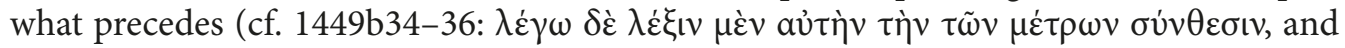

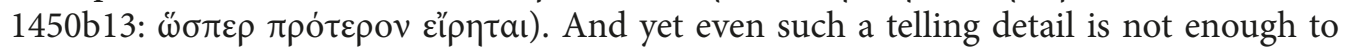
blame him for falsification. Note that the segment is incorporated in a plainly visible manner: its end is marked by a near replica of the transition phrase. This is hardly a proper way to conceal a forgery. His interpolations reveal no desire to defraud a reader; he never disguises himself as an ancient thinker like, for instance, the author of a preface to Theophrastus' Characters does. Rather, he was copying the Poetics for his own use, conceiv-

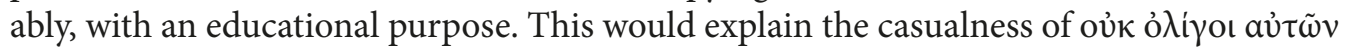

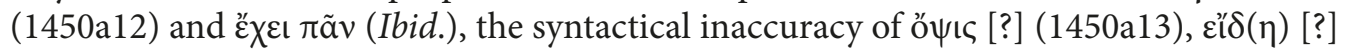

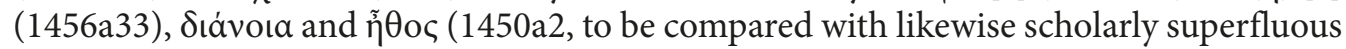

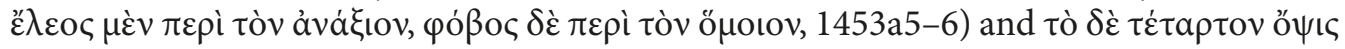

${ }^{48}$ Heinsius 1611, 15. He placed it between chapter VI and VII.

49 The proponents of athetesis as well as of attribution are listed in Else 1957, 360, n. 1.

50 Hence Montmollin $(1951,58-59 ; 125-129)$, who argues for the authenticity of ch. XII, proposes to

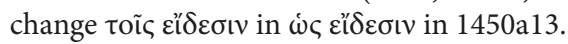

${ }_{51}$ Else 1957, 362. On p. 351 Else cites a nice account of ch. XII by Gomperz ("Polizeiverordnung inmitten eines rechtsphilosophischen Werkes"). 


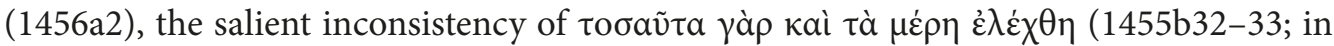
making passing remarks he has no need to remember the exact number!), as well as the 'equalizing' tendency displayed in кaì $\mu \varepsilon \dot{\lambda}$ oc (1449b29), in the definition of poetic speech as 'the composing of verses', further on, in $\tau \tilde{\omega} \nu \mu \grave{\varepsilon} \nu \lambda \hat{\gamma} \gamma \omega \nu \dot{\eta} \lambda \dot{\varepsilon} \xi ı \varsigma$ (1450b12-13), in placing oै $\psi \iota \varsigma$ among the 'kinds' of tragedy, and perhaps most of all, in switching from $\mu \dot{\varepsilon} \rho \eta$ to $\varepsilon \varepsilon^{\prime} \delta \eta$ to denote one and the same thing. The didactic background becomes palpable in the

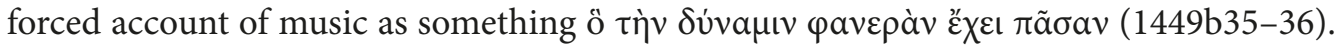
All this creates a general impression of a school copy never intended for use outside the class-room. But if that is true, the maker of $\omega$ had no need to repeat $\omega \varsigma \varepsilon$ है $\delta \varepsilon \sigma \mathrm{l}$ in the clos-

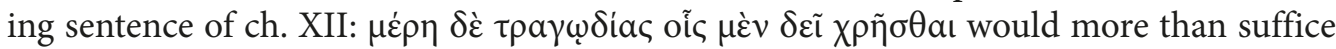
to point back to his own conjecture. Thus, the decision to restore it appears preposterous.

What school it could be is not our present concern, but in contrast to the Eastern translators its master was entirely aware of what the Poetics is all about, and was too wellread in the Greek drama even for a Middle Byzantine scholar. ${ }^{52}$ He wrote in uncials, ${ }^{53}$ inserting most of his supplements directly in the core text or between the lines, the technique presupposing the use of a papyrus roll rather than a parchment codex. His enthusiasm naturally decreases, as he works through the text, and in the last chapters his presence is much less explicit, the conjectures almost lacking. Some of his notes might have been dismissed by the copyists, others reproduced in the mss. now lost. The recent research confirmed by the fresh collation of Syriac and Arabic translations has shown that the earliest reachable branch of transmission, that is the Eastern, is more ramified than previously thought, its archetype (if they stem from any) probably dating back to antiquity. The interpolations which we have attempted to trace could well have originated some half-millennium before the making of $\mathrm{A}$, in the late Neoplatonic period $\left(4^{\text {th }}-6^{\text {th }} \mathrm{c}\right.$.), when Aristotle was read and commented on by many teachers in West and East. As noted by several scholars of the Poetics, the most prominent of them, and whose work on the text of the Poetics is somehow witnessed, was Themistius. ${ }^{54}$

However, to penetrate thus far is barely possible even for the eye of the keenest textual critic, and so this study has to conclude with uncertainties. We have focused on the phenomenon once called by Wilamowitz interpolationum familia. ${ }^{55}$ But, in fact, we cannot

52 One more interpolation coming from an interlinear gloss reveals literary knowledge. It is to be

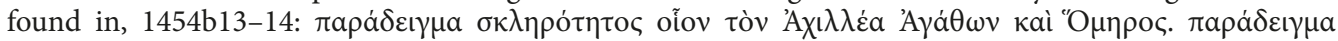

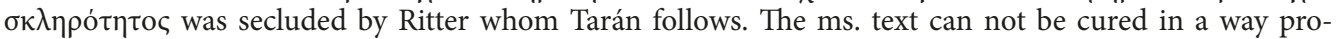

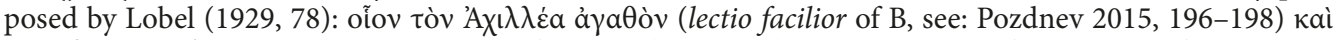

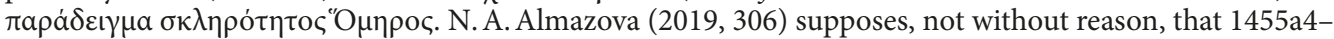

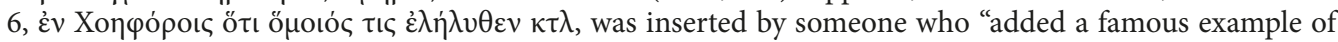

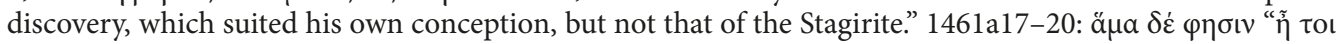

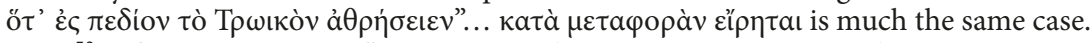

53 Cf. Gutas 2012, 108: " $\Sigma$ was in uncials, representing a stage in the transmission parallel to the hyparchetype from which the extant Greek manuscripts and exemplar of the Latin translation derive." If this is so, there remains no doubt that the common source of $\Sigma$ and other ms. was also in uncials.

${ }^{54} \mathrm{He}$ taught at Constantinople in the mid- $4^{\text {th }} \mathrm{c}$., and as a 'senator' had access to the emperor's library. His glosses in Aristotle's corpus are many. His paraphrase of the Poetics is mentioned in Ibn al-Nadim's Kitāb al Fihrist. See Busch 2008, XXV, with references. And it seems that numbers were not his strong suit,

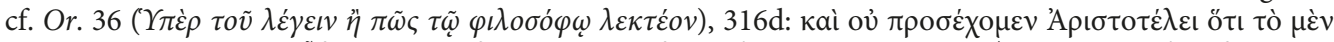

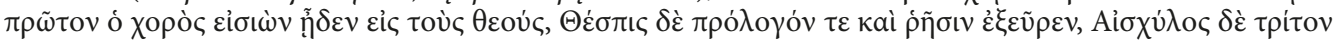

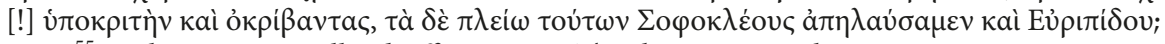

55 Wilamowitz-Moellendorff 1875,205 . The characteristics he gives concerning a group of verse interpolations starting with $\eta$ in Euripides and Sophocles, for all their mordancy, fit well with the above examined 
be sure that these interpolations have originated from one source. They might have been made by several ancient and mediaeval scholars who used the text for teaching purposes. Nor there is any means to clarify if $\omega$ was not a copy of this source, or a copy of this copy. There is a certain, relatively small, number of indicative gaps and mistakes, as well as interpolations, in the transmitted text of the Poetics that do not fall into the mentioned category and thus have found no place in the present discussion (with the only exception of oüc, $1449 \mathrm{~b} 37$, altered in toútous just to render the passage readable). ${ }^{56}$ Any of these faults could have been committed by a person whose supplements we have studied. But they could equally well have been inherited by him from his source or added by the maker of a further copy which should then be thought of as $\omega$. The common ancestor we look for proves to be extremely elusive.

\section{References}

Allan D. J. EI $\triangle \mathrm{H}$ TPAГ $\Omega \mathrm{I} \Delta \mathrm{IA} \Sigma$ in Aristotle's Poetics. CQ 1972, 22, 81-88.

Almazova N. Recognition Based on Paralogism (Aristot. Poet. 1455a12-16). Hyperboreus 2019, 25, 302-327.

[Anonymus (G. Morel?)] (ed.) Aristotelis De arte poetica liber. Paris, apud Guil. Morelium, 1555.

Batteux Ch. (éd., trad., comment.) Les quatre poëtiques: d'Aristote, d'Horace, de Vida, de Despréaux.

Paris, Saillant et Nyon, 1771.

Brescia G. Sul testo e la fortuna della Poetica. Note di critica aristotelica. Milazzo, SPES, 1984.

Bursian C. Zu Aristoteles Poetik. Jahrb. f. cl. Philol. 1859, 5, 751-758.

Busch T. Chronologische Übersicht zur Textgeschichte [sc. der Poetik], in: Schmitt 2008, XVII-XXVI.

Butcher S. H. (ed.) Aristotle. Poetics. Transl. and with crit. notes. London, Macmillan, ${ }^{4} 1911$.

case: "Curabant absurdi homines, ne tragici quidam viderentur omisisse"; "alia quaevis abesse vel potius addi posse visa sunt male sedulis homuncionibus" (Ibid. 206).

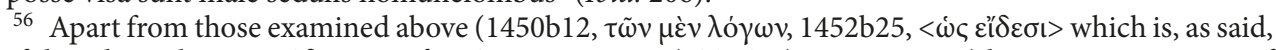

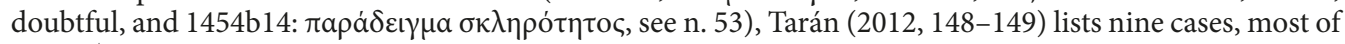

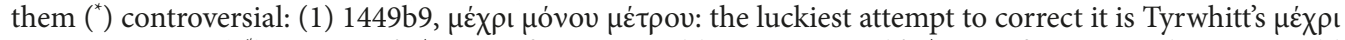

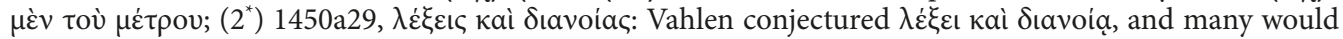
like it, but in fact the ms. reading is tenable, if not that elegant; ( $\left.3^{*}\right) 1452 \mathrm{a} 3$, кai $\mu \tilde{\alpha} \lambda \lambda \mathrm{ov}$ : the athetesis is ques-

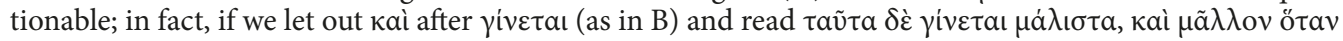

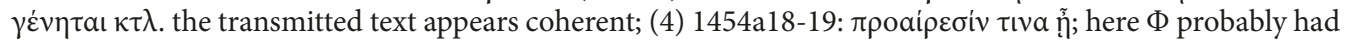

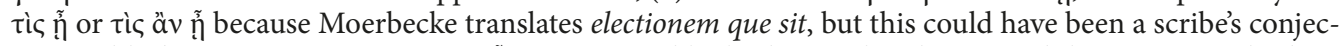

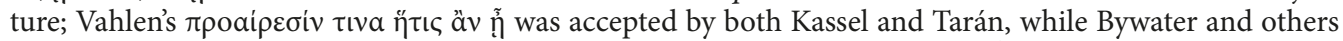
simply deleted $\tilde{\eta}$; in any case the corruption was present in the source text; $\left(5^{*}\right) 1456 \mathrm{~b} 8$, paivolto $\dot{\eta} \delta \dot{\varepsilon} \alpha$ is not that dubious as it is thought of; cf. Rhet. 1369b16; 19; EN 1176a20: EE 1231a1; Probl. 928b19; 23, while Vahlen's ñ $\delta$ Éo meant as a usual expression, almost a colloquialism, is in fact a hapax; (6) 1457b33, where, as

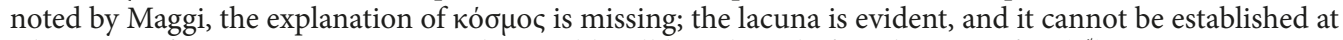
what stage of transmission it appeared; it could well have been before the time of $\omega$; $\left(7^{*}\right)$ 1458a28-29, кatà

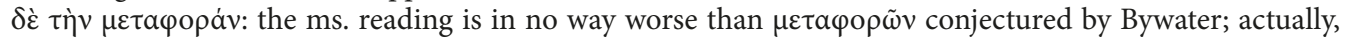
it should be $\tau \grave{\eta} v \tau \tilde{\omega} v \mu \varepsilon \tau \alpha \varphi \rho \rho \tilde{\omega} v$ (sc. $\sigma \dot{v} v \theta \varepsilon \sigma i v$ ), but this is too smooth to have been altered; (8) 1460a13,

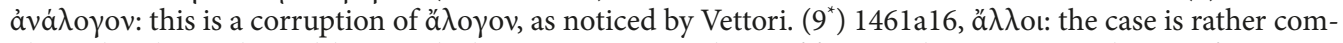
plicated to be explicated here with due care; to cut it short, á $\lambda \lambda$ o i.e. the correct rendering of Homeric

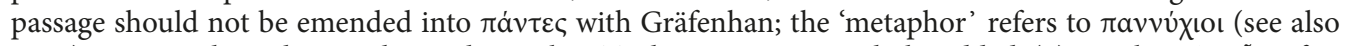
n. 53). Hence at least three archetypal mistakes. To these six more might be added: (1) 1447b29, $\dot{\varepsilon} v$ aĩ : after Vettori $\dot{\varepsilon} v$ oîç is accepted almost unanimously; though the corruption is trivial it is likely to go back to $\omega$;

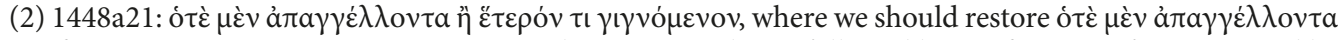

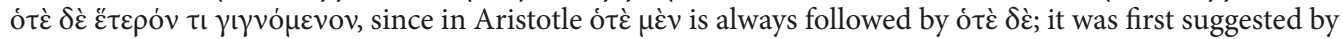
Sahl, rejected by Kassel, and quite reasonably accepted by Tarán; (3) 1448a35, oũtol: Spengel's emedation

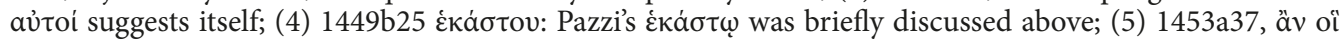

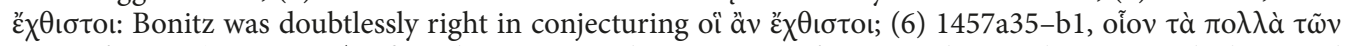

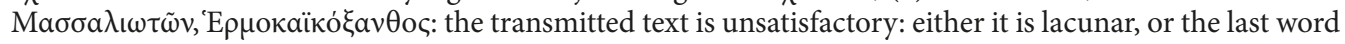
originates from a gloss. 
Bywater I. (ed., transl., comment.) Aristotle on the Art of Poetry. Oxford, Clarendon,1909.

Dupont-Roc R., Lallot J. (eds). Aristote. La Poétique. Texte, traduction, notes. Paris, Éditions du Seuil, 1980.

Else G. F. (ed., comment.) Aristotle's Poetics: The Argument. Cambridge, Ma, HUP, 1957.

Gallavotti C. (ed., comment.) Aristotele. Dell'Arte Poetica. Milano - Roma, Fondazione L. Valla / Mondadori, 1974.

Grayeff F. The Problem of the Genesis of Aristotle's Text. Phronesis 1956, 1/2, 105-122.

Guastini D. (ed., comment.) Aristotele. Poetica. Introd., trad., comment. Roma, Carocci, 2010.

Gutas D. Greek Thought, Arabic Culture: The Graeco-Arabic Translation Movement in Baghdad and Early Abbāsid Society ( $2^{\text {nd }}-4^{\text {th }} / 8^{\text {th }}-10^{\text {th }}$ Centuries $)$. London - New York, Routledge, 1998.

Harlfinger D., Reitsch D. Die Aristotelica des Parisinus gr. 1741. Zur Überlieferung von Politik, Rhetorik, Physiognomonik, De signis, De ventorum situ. Philologus 1970, 114, 28-50.

Hatzimichali M. The texts of Plato and Aristotle in the first century BC, in: M. Schofield (ed.), Aristotle, Plato and Pythagoreanism in the First Century BC. Cambridge, CUP, 2013, 1-27.

Heinsius D. (ed.) Aristotelis De Poetica liber. Leiden, Elsevier, 1611.

Hermann G. (ed.) Aristotelis De Arte Poetica liber. Leipzig, G. Fleischer, 1802.

Janko R. Rec. Tarán, Gutas 2012. CPh 2013, 108, 252-257

Kassel R. (ed.) Aristotelis De arte poetica liber. Oxford, Clarendon, 1965.

Kemal S. The Poetics of Alfarabi and Avicenna. Leiden, Brill, 1991.

Kemal S. The Philosophical Poetics of Alfarabi, Avicenna and Averroes: The Aristotelian Reception. London New York, Routledge, 2003.

Lattmann C. Vom Nutzen der ö $\psi$ ıc: Aristoteles, Poetik 1450a12-14. Philologus 2015, 159/2, 251-271.

Lobel E. The Greek Manuscripts of Aristotle's Poetics. Oxford, OUP, 1933.

Lucas D. W. (ed.) Aristotle. Poetics. Greek text, Latin app., with introd., comment., appendices. Oxford, Clarendon, ${ }^{2} 1972$.

Minio-Paluello L. (ed.) Aristoteles. De Arte Poetica Guillelmo de Moerbeke interprete. Bruges - Paris, Desclée de Brouwer, 1953.

Margoliouth D. Analecta Orientalia ad poeticam Aristoteleam. London, D. Nutt, 1887.

Margoliouth D. The Discussion between Abu Bishr Matta and Abu Sa'id al-Sirafi on the Merits of Logic and Grammar. Journal of the Royal Asiatic Society 1905, 37/1, 79-129.

de Montmollin D. La Poétique d'Aristote. Texte primitif et additions ultérieures. Neuchâtel, Messeiller, 1951.

Pia Pattoni M. Aristotele, Poetica 18, 1456a2-3 e il quarto tipo di tragedia, in: F. Malhomme, L. Miletti et al. (eds). Renaissances de la tragédie. La Poétique d'Aristote et le genre tragique, de l'Antiquité à l'époque contemporaine. Napoli, Giannini, 2013.

Pozdnev M. Honoratus Achilles - the Hero of Two Poetics. Philologia Classica, 2015, 10, 186-202. (In Russian)

Pozdnev M. A Tale of Two Manuscripts, Philologia Classica 2019, 14/1, 141-153.

Reiz F. W. (ed.) Aristotelis De poetica liber. Leipzig, Svikert, 1786.

Schmitt A. (übers., erl.) Aristoteles. Poetik. Berlin, Akademie Verlag, 2008.

Schrier O. J. The Poetics of Aristotle and the Tractatus Coislinianus. A Bibliography from about 900 till 1996. Leiden, Brill, 1998.

Schoder R. V. Literary Sources cited by Aristotle in the Poetics. CJ 1969, 65, 75.

Sicherl M. Die Aldina der Rhetores Graeci (1508-1509) und ihre handschriftlichen Vorlagen. Illinois Classical Studies 1992, 17/1, 109-134.

Spengel L. Rec. F. Ritter (ed.) Aristotelis Poetica. Coloniae, Renard, 1839. ZA 1841, 149, 1252-1275.

Tarán L., Gutas D. (eds). Aristotle Poetics. Editio Maior of the Greek Text with Historical Introductions and Philological Commentaries. Leiden - Boston, Brill, 2012.

Tarán L. The Text of Aristotle's Poetics in the Codex Parisinus Graecus 2038. Mnemosyne 2016, 69/5, 785-798.

Tkatsch J. (ed.) Die arabische Uebersetzung der Poetik des Aristoteles und die Grundlage der Kritik des griechischen Textes. Wien - Leipzig, Hölder-Pichler-Tempsky, 1928-1932.

Tyrwhitt T. (ed.) Aristotelis De poetica liber. Textum rec., versionem refinxit, animandvers. illustravit. Oxford, Clarendon, 1806.

Valgimigli M. Note di critica testuale alla Poetica d'Aristotele. Atti R. Istit. Veneto. 1937, 96, 1-21.

Verdenius W. J. Rec. Else 1957. Mnemosyne 1960, 13/3, 256-258.

Weinberg B. From Aristotle to Pseudo-Aristotle. Comparative Literature 1953, 5/2, 97-104.

von Wilamowitz-Moellendorff U. Analecta Euripidea. Berlin, Borntraeger, 1875.

Received: July 25, 2020

Accepted: October 27, 2020 